\title{
Macro- and microfeatures of Early Cambrian dolomitic microbialites from Tarim Basin, China
}

\author{
Ying $\mathrm{Li}^{1,2,3}$, Hong-Xia Jiang ${ }^{4^{*}}$, Ya-Sheng Wu $\mathrm{W}^{1,2,3^{*}}$, Wen-Qing Pan ${ }^{5}$, Bao-Shou Zhang ${ }^{5}$, Chong-Hao Sun ${ }^{5}$ and \\ Guo Yang ${ }^{5}$
}

\begin{abstract}
The fabrics of microbialites preserved in limestones are generally better than in dolostones. What are the fabrics of the microbialites preserved in heavily dolomitized dolostones? This paper presents an example of a strongly dolomitized Cambrian microbialite profile. The Xiaoerblak Formation (Cambrian Series 2 Stage 3 and lower Stage 4) of the Sugaitblak section in Aksu, Xinjiang Uygur Autonomous Region, China is mainly composed of microbial dolostones. Due to strong alteration by diagenesis, their features, formation and environments have not been fully understood. Here, based on detailed observation on outcrops and thin sections, we show that this formation comprises four kinds of microbialites: laminite, thrombolite, thrombolitic laminite, and Renalcis framestone, in five intervals (Interval I to Interval V). We identified three main types of microbialite fabrics, i.e., clotted fabric, laminated fabric and skeletal fabric, and established a high-resolution vertical evolution sequence of the microbialites. The clotted fabric and the laminated fabric were further divided into subtypes. We found that the original fabrics were mainly affected by dolomitization, recrystallization and dissolution, and the alteration degree of the microbialite fabric is stronger in the lower part of this formation. The laminated fabric has the strongest resistance to diagenesis, followed by the clotted fabric. Based on studies of different rock types and sedimentary structures, we concluded that the sedimentary environment of Xiaoerblak Formation consists of three settings: a) Intervals I to III formed in restricted tidal flat environments, b) Interval IV and the lower part of Interval $V$ in restricted deep subtidal environments, and c) upper part of Interval $V$ in shallowing-up open subtidal environments.
\end{abstract}

Keywords: Cambrian, Microbialite, Thrombolite, Fabrics, Laminite

\section{Introduction}

The term 'microbialite' was first proposed by Burne and Moore (1987) and later modified by Riding (1991) to 'microbolite', referring to the organosedimentary deposits formed by benthic microbial communities through trapping, binding detrital particles, and microbially-induced calcification. Cyanobacteria, bacteria, archaea and microalgae are considered as the main microorganisms involved in microbialite formation

\footnotetext{
* Correspondence: jianghx@mail.igcas.ac.cn; wys@mail.igcas.ac.cn

${ }^{4}$ Hebei GEO University, Shijiazhuang 050031, China

${ }^{1}$ Key Laboratory of Cenozoic Geology and Environment, Institute of Geology and Geophysics, Chinese Academy of Sciences, Beijing 100029, China
} Full list of author information is available at the end of the article
(Golubic 1973; Riding 1991). Microbialites are widely distributed throughout most of the history of the Earth. According to the mesostructures, microbial carbonates can be divided into stromatolites, thrombolites, dendrolites, laminites, oncolites and leiolites (Aitken 1967; Riding 1991; Braga et al. 1995; Han et al. 2009). Besides, $\mathrm{Wu}$ et al. (2018) proposed the term caststone for the rocks mainly composed of cast fossils of microbes, which is replaced here by castolite. The fabrics of microbialites are the basis for recognizing, understanding, and classifying microbialites, as well as determining their formation environments, and predicting their spatial and temporal distribution. 
The Cambrian Period is a significant era for the development and evolution of microbial carbonates, representing a distinct transition in the types of microbialites (Shapiro 2004). During the Cambrian the thrombolites and dendrolites became widespread and stromatolites were still widely distributed in spite of the decline in diversity and abundance following the Proterozoic (Aitken 1967; Glumac and Walker 1997). The dominant view is that the decrease in atmospheric $\mathrm{CO}_{2}$ concentration in the Early Cambrian promoted the cyanobacteria calcification mechanism (CCM), and calcified microbial fossils began to appear widely in laminated stromatolites, nonlaminated thrombolites and dendrolites (Riding 2006, 2012). With the Cambrian explosion and the radiation of metazoans such as archaeocyaths, coralomorphs and siliceous sponges, reefs and calcified microorganisms (e.g. Epiphyton, Renalcis and Girvanella) began to appear in Early Cambrian strata (Terreneuvian and Series 2) in large quantities, and the number of microbialites dramatically decreased (Rowland and Gangloff 1988; James and Gravestock 1990; Wood 1999). At the end of Cambrian Series 2, the extinction of the main metazoans reduced the competition for resources with microorganisms. The microbialite started to recover and flourish gradually till the Early Ordovician together with sparse sponges (Wood 1998; Kiessling 2009; Adachi et al. 2011). The North China Platform received sedimentation at the end of Cambrian Series 2, and microbialites developed during the Miaolingian and Furongian Series (Chen et al. 2014). The Miaolingian microbialites are mainly composed of thrombolites and dendrolites, with Epiphyton as the main rock-forming microorganism, while the Furongian microbialites are mainly columnar stromatolites, almost without Epiphyton (Lee et al. 2010, 2014). On the South China tectonic plate, the microbialites and archaeocyaths-microbial reefs occurred in the Cambrian Series 2 (Wang et al. 1990, 2014). To date few studies have been carried out on the Cambrian microbialites in South China, and there is no report of Furongian microbial reefs. Cambrian microbialites in the Tarim Basin, Xinjiang Uygur Autonomous Region, China are widely distributed and are obviously different from those in North China and South China: they are generally composed of dolostones and contain rare fossils, and are mainly found in Cambrian Series 2 Stage 3 and lower Stage 4 Xiaoerblak Formation, Miaolingian Wuliuan Shayilik Formation (Huang et al. 2016; Zhu et al. 2019) and Miaolingian Guzhangian Xiaqiulitag Formation (Huang et al. 2016). The outcrops of the Xiaoerblak Formation in Keping area, Xinjiang are well exposed. Research has been conducted on the microbial carbonates of this formation (Song et al. 2012, 2014; Li et al. 2015; Xiong et al. 2015; Bai et al. 2018; Zheng et al. 2019). Due to the strong alteration of fabrics by diagenesis and the destruction of original features of the microbialites, it is rather difficult to understand their formation mechanism and environments, and the results are controversial, which resulted in the inaccuracy in establishing sedimentary facies models, and failure in several exploration wells targeting at the reservoirs of this formation.

In this study, the macro- and microfeatures of Early Cambrian dolomitic microbialites from Tarim Basin, China were analyzed and described. The microfabrics of the microbialites were identified and classified. The formation environments of this formation were discussed.

\section{Geological settings}

The study area is located in the northwestern margin of the Tarim Basin (Fig. 1a), and tectonically belongs to the eastern part of the Keping fault uplift of the Tabei uplift, approximately $90 \mathrm{~km}$ away from Aksu City. At the end of the Neoproterozoic, the Tarim Plate began to split under the influence of a series of extensional movements, and successively went through rifting, depression and shallow sea deposition periods, forming three isolated carbonate platforms during the Early Cambrian, namely, the Western Tarim, Rossi and Kuluketag platforms. The Western Tarim platform distributes the largest area of the three. The study profile is located at the northwestern edge of the Western Tarim platform for its superb outcrops of the Cambrian (Zhao et al. 2011; Zheng et al. 2019). According to the latest stratigraphic division scheme (Huang et al. 2017; Zhu et al. 2019), the Xiaoerblak Formation in the Keping area overlies the Yuertusi Formation of the Terreneuvian and is overlain by the Usugar Formation of the Series 2 (Fig. 1b). The Yuertusi Formation is a succession of siliceous rocks, black shales and argillaceous carbonate deposits, varying in thickness from $1 \mathrm{~m}$ to $20 \mathrm{~m}$, and is a good source rock. In the later period, the carbonate platform continued prograding northwestwards, and gradually evolved into firstly a restricted platform and later an open platform during the sedimentation of the Xiaoerblak Formation. The Xiaoerblak Formation comprises more than $100 \mathrm{~m}$ of dolostones, and can be clearly subdivided into two members by color of outcrops (Fig. 1c): the Lower Member and the Upper Member. The Lower Member is composed of dark gray thin-bedded dolomicritic dolostones, and the Upper Member is mainly light-colored, thin- to medium-bedded or mound-bearing bedded dolostones, which have better physical property as the main exploration target. In this paper, a detailed study of the microbial carbonates of the Xiaoerblak Formation in the Sugaitblak section in Aksu area, Xinjiang was carried out, based on field observations and thin section examination. 

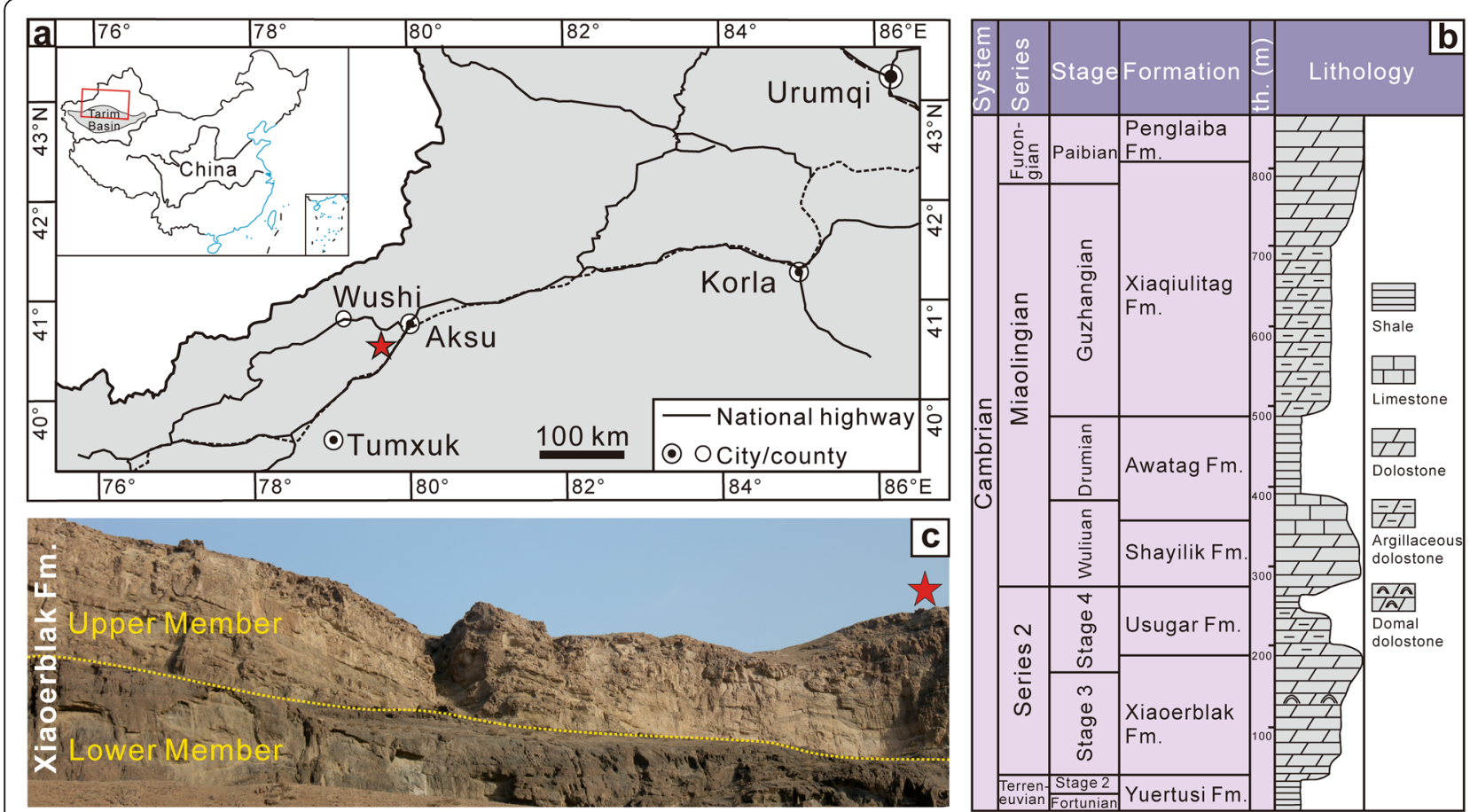

Fig. 1 a Map of the northwestern margin of the Tarim Basin and location of the Sugaitblak section (red star) (after Li et al. 2015). The inset map of China is modified after the Standard Map Service of the National Administration of Surveying, Mapping and Geoinformation of China (http:// bzdt.ch.mnr.gov.cn/) (No. GS (2016)1603); b Stratigraphic framework of the Terreneuvian and Series 2, Cambrian in Keping area, Tarim Basin (after Huang et al. 2017; Zhu et al. 2019); c Outcrop photograph of the Sugaitblak section (red star)

\section{Method and terminology}

A series of outcrop data were collected for laboratory analyses including GPS coordinates, photographs, samples, altitude and thickness of strata, lithology association, special textures and structures of rocks. A total of 120 petrographic thin sections were made from the samples collected at 1.5 $\mathrm{m}$ interval on average, and were analyzed under the plane polarized light (PPL) and cross polarized light (XPL).

The term 'laminite', which Friedman et al. (1973) defined, refers to the biogenetic laminated carbonate rocks related to algal mats. Monty (1976) proposed the term 'cryptalgal laminites' for one of the three types of layered cryptalgal carbonates that are laterally continuous and characterized by a subcontinuous planar lamination ranging from less than a millimeter to several centimeters. In this paper we use 'laminite' to refer to sheet-like laminated microbialite.

The term 'thrombolitic laminite' used here refers to the laminite that consists of thin dark-colored dolomicritic laminae and the alternative thick clotted layers. The terms 'mesoclot' and 'microclot' are used for clots of different scales, the former for clots on cm-scale, and the latter for clots on mm-scale (Shapiro 2000).

\section{Outcrop characteristics}

According to this field measurement, total thickness of the Xiaoerblak Formation in the Sugaitblak section is
$187 \mathrm{~m}$. All thin sections were smeared with mixture of mordant red 3 and 5\% diluted hydrochloric acid for 30 seconds, slowly rinsed with running water for $3 \mathrm{mi}-$ nutes. Only a few thin sections from the top of the Lower Member turned red, indicating that the Xiaoerblak Formation mainly consists of microbial carbonates which are almost entirely composed of dolostones. The microbialites present two kinds of shape on outcrop. The Lower Member is characteristically thin- to medium-bedded, the lower part of the Upper Member is thin-bedded, and contains scattered microbial mounds, and the middle-upper part of the Upper Member is medium- to thick-bedded. The main types of microbialites include thrombolite, laminite, thrombolitic laminite and some microbial framestones. According to lithology, the Lower Member can be subdivided into three parts (Intervals I to III; Fig. 2), and the Upper Member is further divided into two parts (Intervals IV and V).

Interval I is $35 \mathrm{~m}$ thick of black thin-bedded dolomicritic dolostone (Figs. 2, 3a), powder crystalline dolostone, and some coarse crystalline dolostone, with a single layer being $2-10 \mathrm{~cm}$ thick. Birdseye structures occur at the bottom of this interval (Fig. 3b). The birdseye structures have regular shapes, generally in the shape of flat ellipses, and have a size of $(0.2-1.5 \mathrm{~mm}) \times$ $(0.2-0.5 \mathrm{~mm})$. The birdseyes are unevenly distributed, 


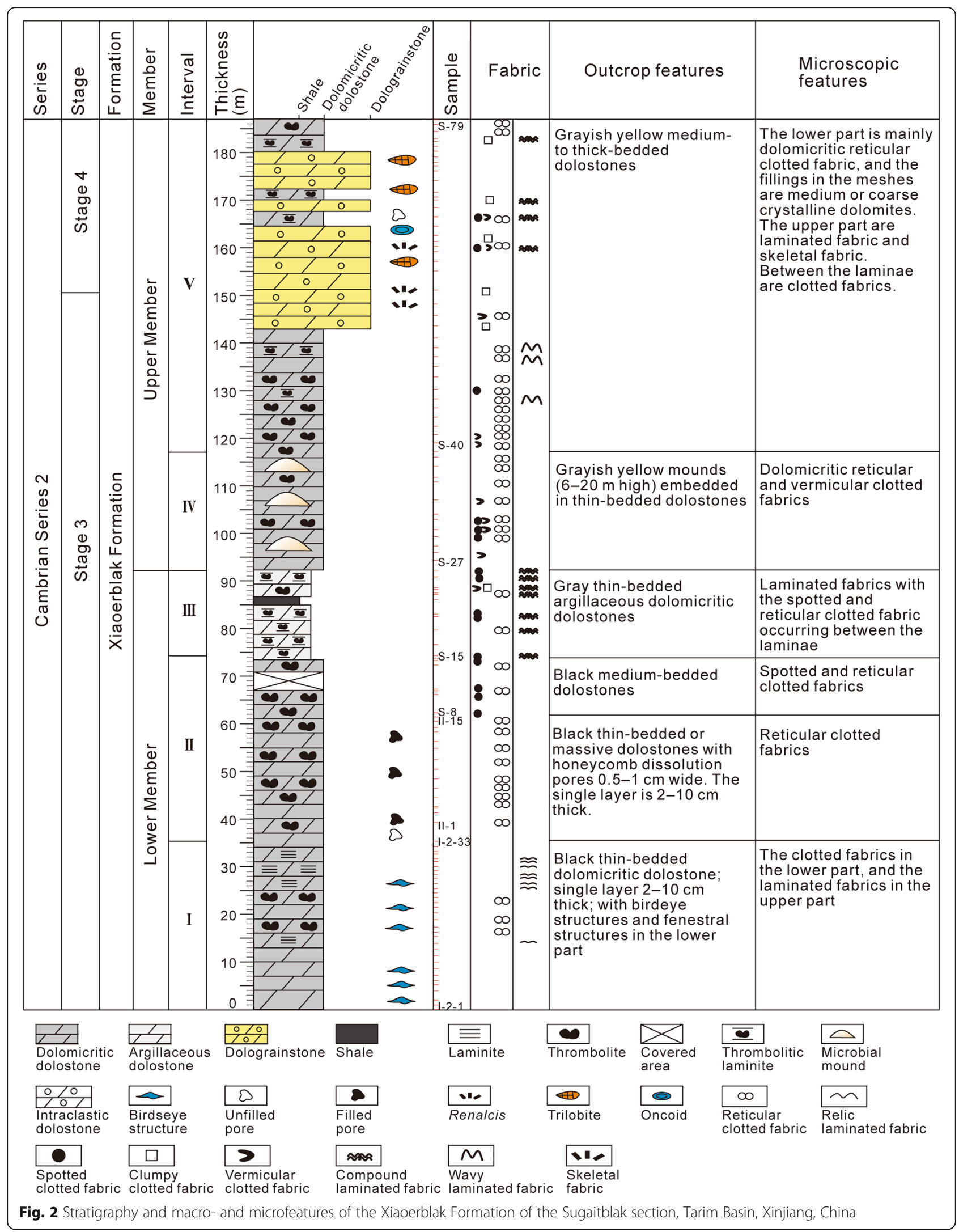



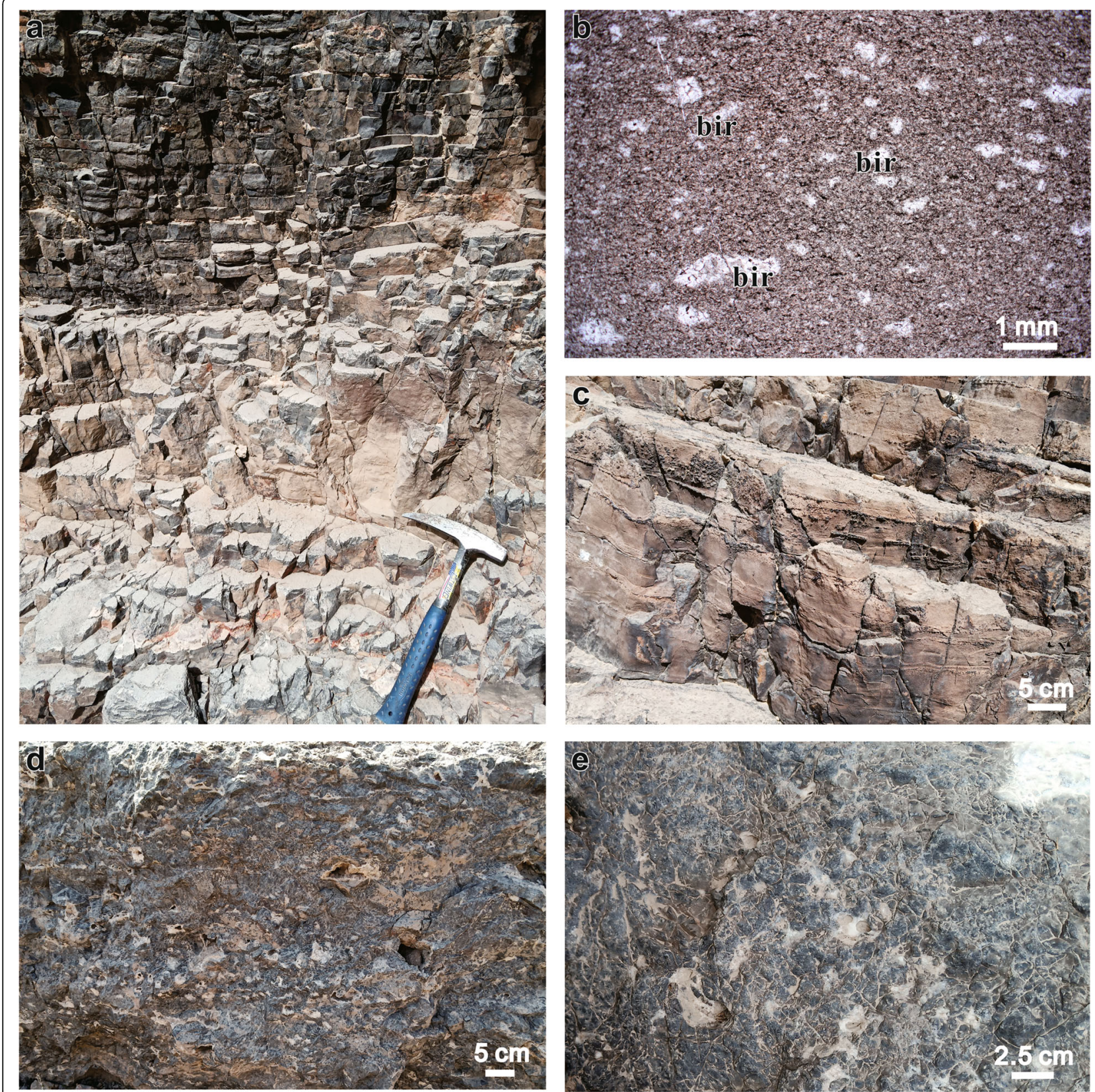

Fig. 3 Outcrop and thin section features of Intervals I and II of the Xiaoerblak Formation (Cambrian Series 2) of the Sugaitblak section, Tarim Basin, Xinjiang, China. a Black thin-bedded dolomicritic dolostone in Interval I. A single layer is $2-10 \mathrm{~cm}$ thick. Hammer length $=35 \mathrm{~cm}$. b Micrograph of birdseye structures (bir) in lower part of Interval I. The sparry calcite filled granulated birdseyes are variable in size $(0.1-1 \mathrm{~mm}$ in diameter) and are unevenly distributed. c Thin-bedded laminites in the upper part of Interval I with straight parallel laminae. $\mathbf{d}$ and e Black honeycomb dolostones in Interval II with hollow pores and calcite-filled pores

and in some places are arranged into horizontal lines. The birdseye structures gradually decrease upwards and the laminites (Fig. 3c) appear simultaneously in the upper part of Interval I, probably due to change in the depositional environment. The laminites are comprised of powder and fine crystalline dolomites without grainy sediments. The laminations in the laminites are parallel, straight and laterally continuous, and have a uniform interval of less than or equal to $1 \mathrm{~cm}$.

Interval II is about $38 \mathrm{~m}$ thick, seems to be thinbedded, in black color on fresh outcrops, with dissolution pores in several horizons, giving the outcrops a honeycomb appearance (Fig. 3d, e). The horizons without dissolution pores are composed of fine dolomite. 

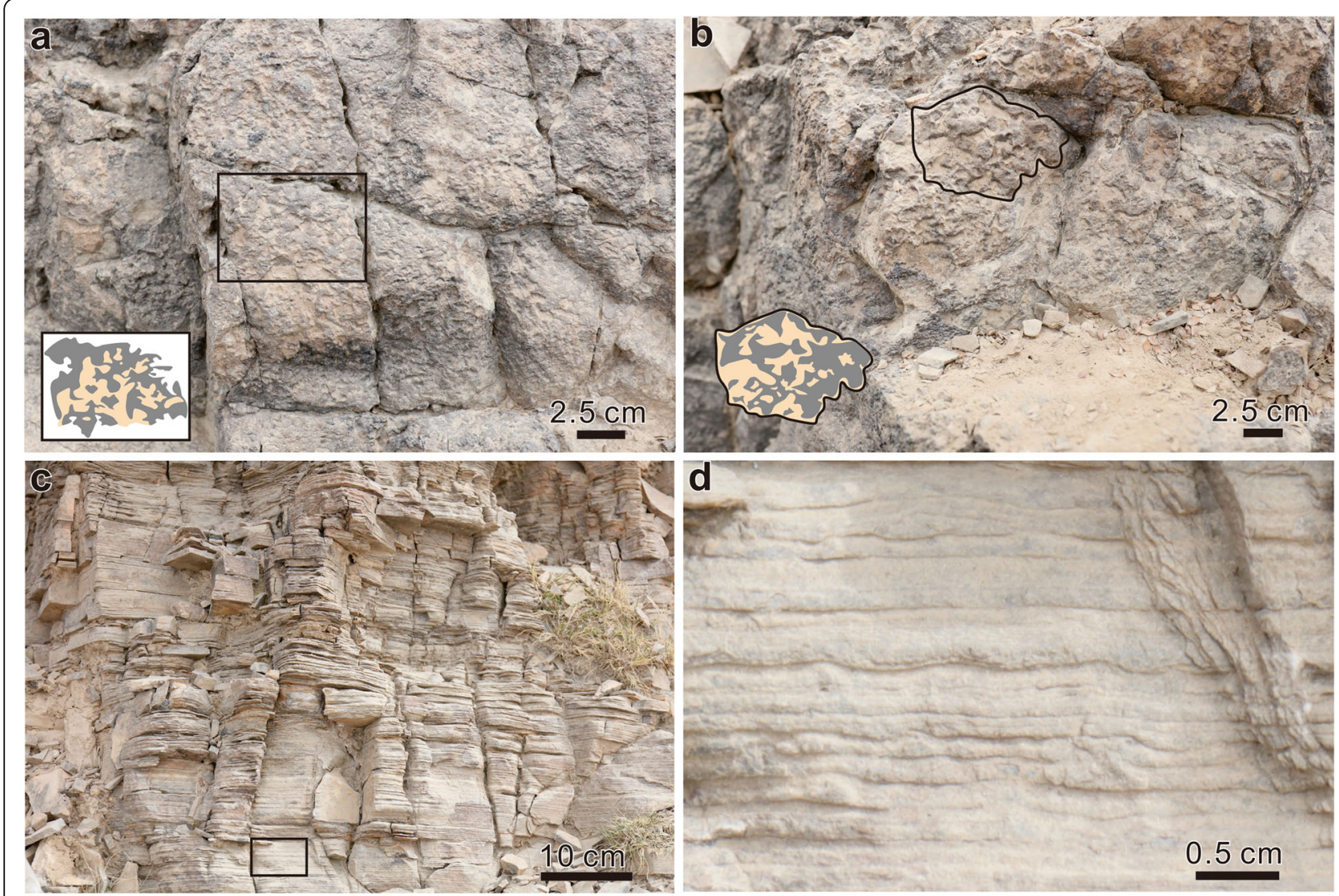

Fig. 4 Outcrop and thin section features of the upper part of Interval II and the Interval III of Xiaoerblak Formation (Cambrian Series 2) of the Sugaitblak section, Tarim Basin, Xinjiang, China. $\mathbf{a}$ and $\mathbf{b}$ Stratiform thrombolites at the top of the Interval II. Some dark mesoclots (marked in gray color) are fused with each other and interconnected with width less than $2 \mathrm{~cm}$, composed of fine and microcrystalline dolomites or clay-sized minerals, and the inter-clot brighter spaces (marked in pale orange color) are cemented by medium or coarse dolomites. c Thin-bedded argillaceous dolomicritic dolostones in the Interval III. d Close-up of the black square in the lower part of c. Most laminae are continuously straight with few in microrelief. The dark fine dolomite laminae and the light coarse dolomite laminae are parallel to each other and the thickness of them is less than $0.3 \mathrm{~cm}$

The honeycomb horizons are composed of fine to medium dolomites. The pores are usually lenticular or irregular in shape, being $0.5-2 \mathrm{~cm}$ in diameter and averaging $0.8 \mathrm{~cm}$, spacing at $2-10 \mathrm{~cm}$ distances, and account for $30 \%-50 \%$ of the rocks. Some pores are hollow (Fig. 3d), while others are almost wholly filled with calcite (Fig. 3d).

A succession of 10-m-thick stratiform thrombolites occurs at the top of this interval, as $5-10 \mathrm{~cm}$ thick planar beds without laminations (Fig. 4a, b). These thrombolites are characterized by a framework of the mottled surface attributed to the contrasting fine and coarse dolomite. The mesostructure is comprised of a net-like framework of mesoclots. Most of the mesoclots are fused with each other and interconnected, composed of fine and microcrystalline dolomites or clay-sized minerals, and the inter-clot spaces are cemented by medium or coarse dolomites. The mesoclots are mm-scale, with a width of less than $1 \mathrm{~cm}$, and have conspicuous margins without obvious orientation. The bulging body of mesoclots exhibits a stronger weathering resistance than the inter-clot rocks.

Interval III is $20 \mathrm{~m}$ thick, mainly composed of gray thin-bedded argillaceous dolomicritic thrombolitic laminites (Fig. 4c, d). The thrombolitic fabrics are $\mathrm{mm}$-scale, so analysis of them mainly depends on microscope. On the outcrops, the laminations have a high content of argilla and are yellow-greenish in color. The laminations are laterally continuous and slightly crinkly. The dark fine dolomite laminae and the light coarse dolomite laminae form $0.2-0.3 \mathrm{~cm}$ thick couplets. The single lamina is extremely thin, and often ranges from $0.3 \mathrm{~cm}$ to 0.1 $\mathrm{cm}$ in thickness (Fig. 4d).

Interval IV is about $25 \mathrm{~m}$ thick, containing scattered thrombolitic mounds, and the intermound facies is dark thin-stratiform dolostone with a single bed in $\sim 10 \mathrm{~cm}$ thick. Differing from the traditional microbial reefs built by various types of calcimicrobes and shelly metazoans (Shapiro 2004), the mounds are mainly comprised of 


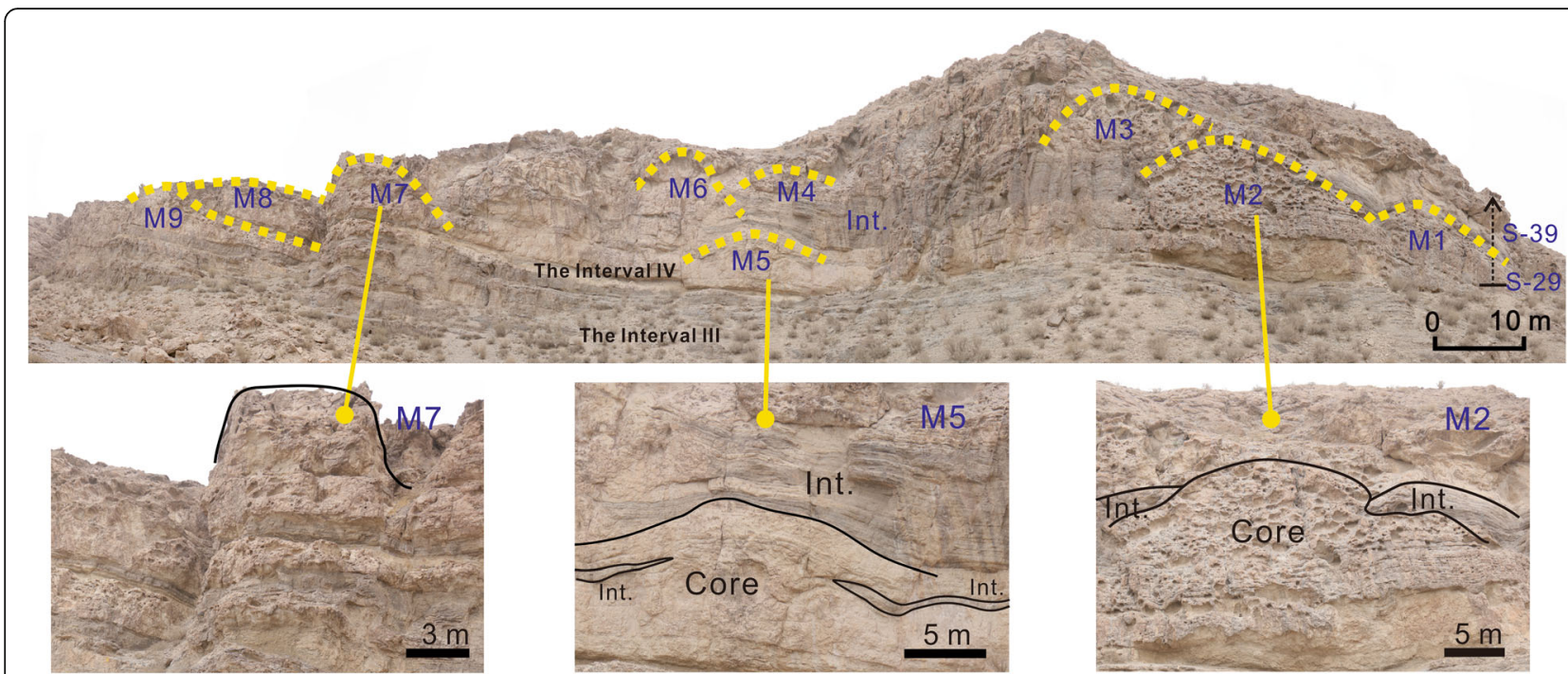

Fig. 5 Outcrops of the microbialite dolostones of the Interval IV of the Xiaoerblak Formation (Cambrian Series 2) at the Sugaitblak section, Tarim Basin, Xinjiang, China. The Interval IV which overlies the Interval III corresponds to thin sections S-29 to S-39. Interval III is covered by earth. The massive microbial mounds (M1 to M9) are in various sizes with dolomicritic cores and the rocks between the mounds (Int.) are black thin-bedded dolostones

dolomicritic dolostones and fine crystalline dolostones lacking fossils. A total of nine microbial mounds (M1M9) were observed within an outcrop wall of $150 \mathrm{~m}$ wide and $20 \mathrm{~m}$ high (Fig. 5). The mounds are in various sizes, mostly in domelike shape (M1-M6) and others being irregular (M7-M9). The width of mounds is about $10 \mathrm{~m}$ on average and the height is less than $10 \mathrm{~m}$. The mounds are internally massive without laminations and conspicuous sedimentary structures. It is difficult to distinguish the mesostructures on the surface of dome thrombolites in this interval, and all of the structural features are based on the microscale observation.

Interval $\mathrm{V}$ is about $69 \mathrm{~m}$ thick, composed of grayish yellow thin- to medium-bedded dolostones (Fig. 6a). Its lower part is mainly dolomicritic thrombolitic dolostone without clear mesoclots on the surface like the thrombolites in Interval IV; while the upper part consists of dolograinstones, with a few trilobite fossils. There are various types of microbialites in the upper part such as thrombolitic laminites, Renalcis framestones, clumpy thrombolites and some stromatolites (Fig. 6c). The thrombolitic laminite is a combination of superposed laminites and thrombolites making up $50 \%-60 \%$ of the total microbialites. The dolomicritic laminae in thrombolitic laminite are usually laterally continuous but crinklier than those in Interval III. In some places the laminae are gently convex with truncated laminae on both sides. The single layer of laminites is about $0.5 \mathrm{~cm}$ in thickness on average, slightly thinner than the $0.5-1-\mathrm{cm}$-thick thrombolitic layers between them. The mesoclot in thrombolitic layer is irregular and chaotic (Fig. 6b), and much smaller than that in Interval II. The thrombolitic laminites gradually decrease up the section, with an increase in the sand-sized intraclasts, indicating change in environmental conditions.

\section{Fabrics}

The fabric of microbialites refers to the size, shape and arrangement of their minerals. The variety of fabric features can reflect different hydrodynamic conditions, deposition rates, types of microbial communities, seawater temperature and saturation, and other environmental conditions (Turner et al. 1997). The fabrics of microbialites can be observed and described on different scales. At present, the classification of fabrics on mesoscale (e.g., polylobate, mesoclots, etc.) and microscale (e.g., peloids, filamentous microbial cements, spherulites, etc.) of Shapiro (2000) are widely used. The mesoscale fabrics are $\mathrm{cm}$-sized and are visible to the naked eyes, and consist of mesoclots and the lighter-colored patches between them, or dark-colored laminae and the alternative lighter-colored laminae. The microscale fabrics $(<1 \mathrm{~mm})$ are the microscopic petrographic characteristics of the mesoclots that can only be observed under microscopes. Based on mesoscale features, Riding (2011) divided microbialites into dendrolites, stromatolites, thrombolites and leiolites.

The study of fabrics on the microscopic scale is important to explore their genetic mechanism and forming environments. Laminated fabric and clotted fabric are the most common two types of fabrics. In addition to them, there are skeletal fabric, binding fabric and other 

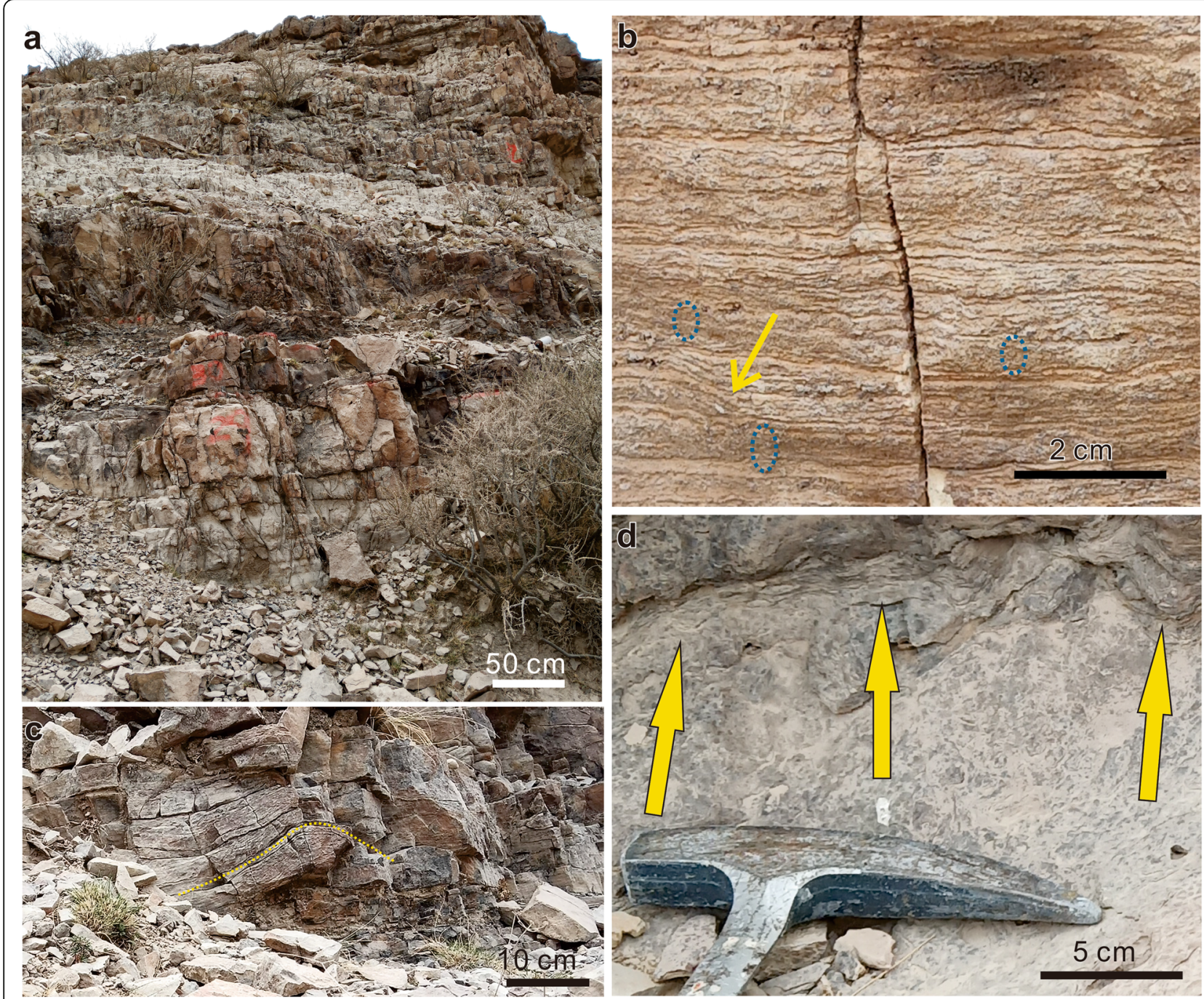

Fig. 6 Outcrop features of Interval V of the Xiaoerblak Formation (Cambrian Series 2) at the Sugaitblak section, Tarim Basin, Xinjiang, China. a Grayish yellow thin- to medium-bedded dolostones. $\mathbf{b}$ The thrombolitic laminites. The laminae are continuous in the interval of less than $0.5 \mathrm{~cm}$. Sometimes the laminae became convex in shape (in yellow arrow). Between the laminae are thrombolitic layers (in blue dashed circles) and the mesoclots are too small to distinguish being chaotic. c The dome-like stromatolite (in yellow dashed line) in the upper part composed of dolomicrite in the height of about $13 \mathrm{~cm}$. $\mathbf{d}$ Densely distributed microbial mat relics-like laminations (in yellow arrows) in thrombolitic laminites

types (Wu et al. 2018). From thin section examination, two main fabrics are identified: a) the laminated and clotted fabrics, which are the most common and variable features in this formation, and b) skeletal fabrics (Fig. 2). Researchers have made preliminary studies on the microbialites in this formation (Song et al. 2012; Huang et al. 2016), but they are all on mesoscale, lacking detailed description and classification of microscale fabrics. In this study, the features and classification of microscale fabrics are detailed, the clotted fabrics are further divided into four subtypes: vermicular clotted fabric, reticular clotted fabric, spotted clotted fabric and clumpy clotted fabric, and the laminated fabric is subdivided into two subtypes: wavy lamination and compound lamination.

\subsection{Clotted fabric}

Clot is the basic component of thrombolites, being dark in color, having distinct and irregular edges, and is composed of micrite or dolomicrite. It was considered to be the framework of the thrombolites (Aitken 1967), and formed from microbially-induced calcification or sediment-trapping. Clots can be divided into mesoclots and microclots based on scales. In the past 50 years, the studies on ancient microbialites focused on the interpretation and description of mesoclots. According to morphology, Du (1992) divided mesoclots into porous clots, mottled clots and reticular clots. Riding (2000) divided the thrombolite into seven categories in terms of their genesis, including calcified microbial thrombolite and coarse agglutinated thrombolite. Harwood Theisen and Sumner (2016) 
classified Cambrian thrombolites in the Great Basin into eight types, including hemispherical microdigitate, bushy, coalescent columnar and massive fenestrated.

Except for the description of mesoscale characteristics of microbialites in the Xiaoerblak Formation, the microscale features are the prime focus in this paper. It is worth noting that the term 'clotted fabric' used in this article refers in particular to microclot fabrics. Our microscopic examination reveals that the thrombolitic microclots in the Xiaoerblak Formation is internally composed of dolomicrite or powder crystalline dolomite, and are in different shapes (e.g., vermicular, elliptical, irregular, reticular, etc.). The light-colored material between microclots is composed of fine dolomites, medium dolomites, or coarse dolomites, and are called bright spots. The bright spots have relatively smooth edges, and are distinct from the dissolution pores which generally have bay-shaped outlines, and may represent the primary pores formed in the growth stage, but filled with cement during the diagenesis stage. The primary pores can have two origins: the pores left by the microbes that had functioned as builders during the formation of the microbialites, but decomposed after their death, and the remaining voids among the microclots. The former type is usually small in size and require microscope study. On the basis of the morphology of microclots, the clotted fabrics are further classified into the four fabric subtypes: vermicular clotted fabric, reticular clotted fabric, spotted clotted fabric and clumpy clotted fabric.

\subsubsection{Vermicular clotted fabric}

The vermicular microclots are expressed by an undirected arrangement of worm-like dark clots in the bright matrix (Fig. 7a, b, c). They are irregularly curved, and are composed of dolomicrites. In this paper, three parameters are used here to constrain the morphology of the microclots, which are length, width and angle of curvature, and we take the total length of the straight segments that comprise a sinuous microclot as its summed length. The length of the vermicular microclots in the thrombolites of this formation varies a lot, ranging from $0.1 \mathrm{~mm}$ to $0.8 \mathrm{~mm}$ with no conspicuous patterns, while the width is relatively uniform, ranging between $0.1 \mathrm{~mm}$ and $0.15 \mathrm{~mm}$. Most of the worm-like microclots are slightly curved with the bending angle concentrated at $150^{\circ}-170^{\circ}$, even some seem like straight rods. All of the vermicular microclots are disorderly distributed within the spar-filled groundmass, most being evenly isolated spacing at an average distance of less than 0.5 $\mathrm{mm}$, but few contacted with each other producing a chaotic area which made the vermicular outline blurred. The cement among the microclots is usually made up of two kinds of dolomites: one is the fine-medium crystalline hoary dolomites. These dolomites are distributed around the microclots usually in irregular shape and showing light-gray shadow on the surface. The other type is the medium to coarse dolosparite which are close to the hoary dolomites and far away from microclots. Bright dolosparite often forms a regular rhombic shape, and is larger than hoary dolomites, which hints at the existence of enough space to grow. There are also some voids between some dolosparite, and they are considered to be the result of burial dissolution for special bayshaped outlines. Overall, the area ratio of the dolomicrites to the cements almost reaches 1:1. The special arrangement of microclots and cements naturally produces a gradual transition of color from dark to bright. However, due to recrystallization, some microclots have been altered from black dolomicrite to yellowish-brown powder crystalline dolomite, making the edge of the vermicular microclots blurred and difficult to separate from the surrounding cements. The vermicular fabric mainly occurs in the Interval IV associating with the reticular clotted fabric, spotted clotted fabric and even laminated fabrics.

\subsubsection{Reticular clotted fabric}

In this fabric the microclots are in irregularly reticular shape, and are composed of dark dolomicrites or fine dolomites (Fig. 7d, e, f). The reticular clotted fabric is the main subtype of the clotted fabric in the Xiaoerblak Formation, and consists of two parts: the meshes and the fillings. The meshes consist of dolomicrite, and have a width of about $0.01 \mathrm{~mm}$. The fillings in the meshes are composed of fine, medium or coarse crystalline dolomite, and are in irregular shape. The diameter of the fillings ranges from $0.01 \mathrm{~mm}$ to $0.5 \mathrm{~mm}$. This kind of fabric mainly occurs in Interval II, Interval IV and the lower part of Interval V. The reticular clotted fabric in Interval II is mainly composed of fine dolomite, and the fillings are mainly medium dolomite, with a diameter of 0.05 $0.13 \mathrm{~mm}(0.1 \mathrm{~mm}$ on average). The reticular clotted fabric in the Interval IV and the lower part of Interval V is mainly composed of dolomicrite, and the fillings are mainly fine dolomite, with average diameter of $0.05 \mathrm{~mm}$. It often appears in combination with the spotted clotted fabric and vermicular clotted fabric. The reticular clotted fabric in the middle part of Interval $\mathrm{V}$ mainly exists in the bright laminae of the laminated fabric, with an average diameter of $0.1-0.5 \mathrm{~mm}$. The reticular clotted fabric has various forms in this interval, but its content is limited, about $20 \%-30 \%$, gradually decreasing upwards.

\subsubsection{Spotted clotted fabric}

In this microfabric, the microclots are spot-like and in dark color, composed of dolomicrite or powder crystalline dolomite (Fig. 8a, b), and have a diameter of about 

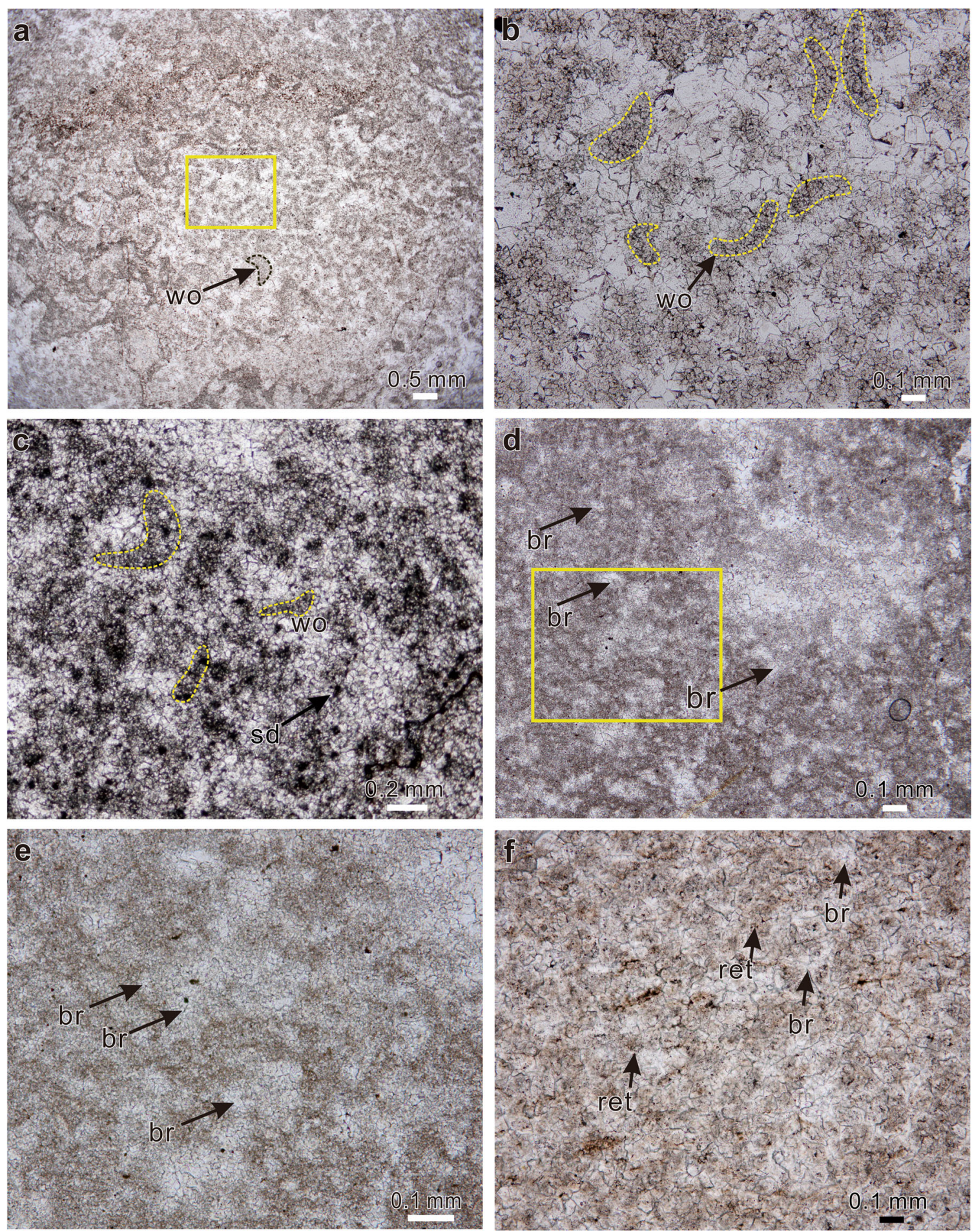

Fig. 7 Microscopic features of the vermicular and reticular clotted fabrics of the Xiaoerblak Formation of the Sugaitblak section, Tarim Basin, Xinjiang, China. a Vermicular clotted fabric, showing vermicular clotted fabric (wo) composed of dark powder crystalline dolomites, at the top of the Interval III, isolated, cemented by light fine dolomites. $\mathbf{b}$ Enlargement of the yellow rectangle in $\mathbf{a}$. The worms are in similar sizes (0.3 mm in length on average) and distributed in isolation without obvious directions. c Spotted (sd) and vermicular clotted fabrics (wo) comprised of dolomicrites, in the microbial mounds in the Interval IV, cemented by fine dolomites. d Reticular clotted fabric of the top of the Interval V. e Enlargement of the yellow square in $\mathbf{d}$, showing the fillings (br) in the meshes composed of fine crystalline dolomites. The meshes are in oval or irregular shape and vary in size. $\mathbf{f}$ The reticular clotted fabric (ret) of the middle part of the Interval I, consisting of fine crystalline dolomites. All are photomicrographs of thin sections under plane-polarized light microscope 

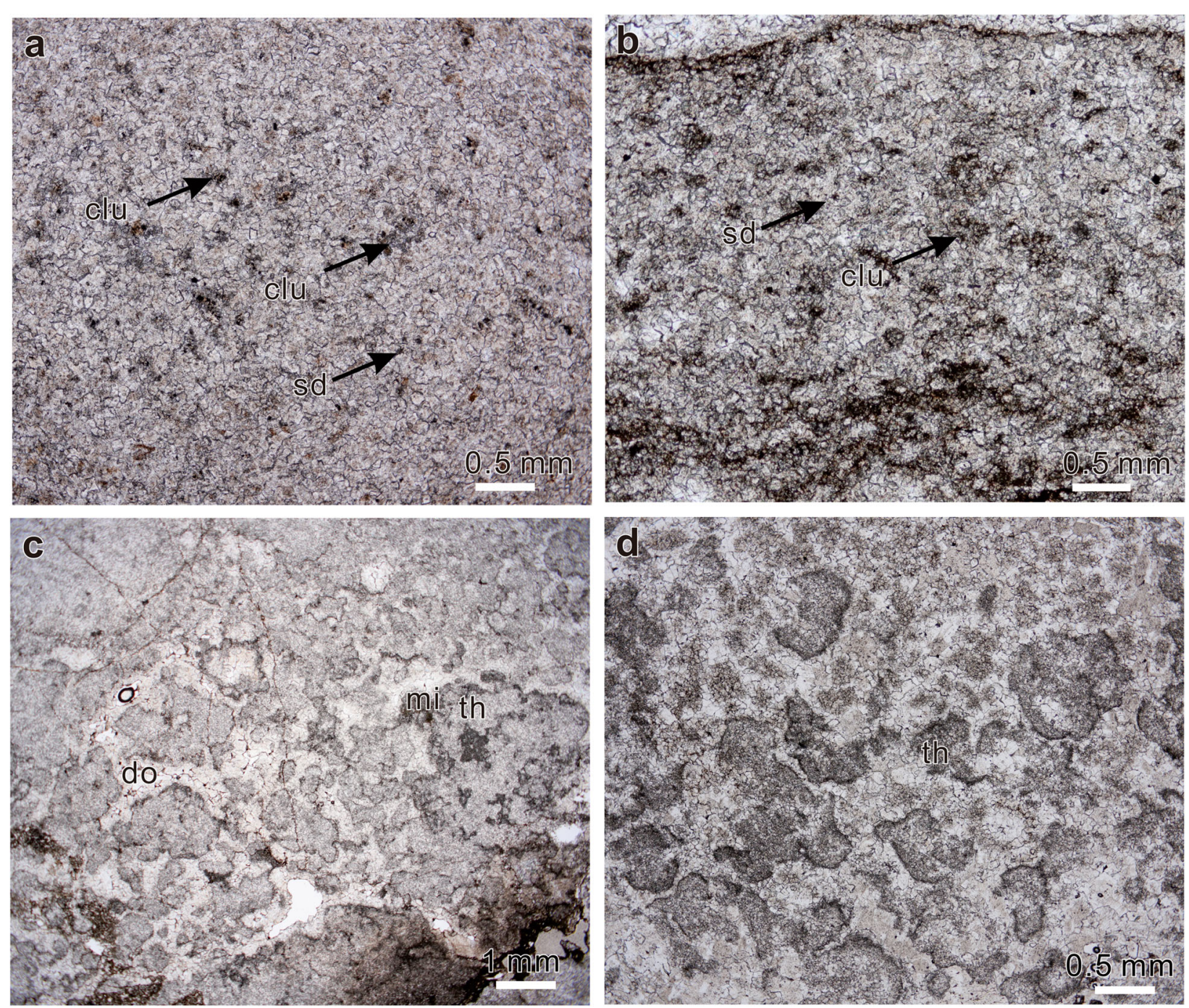

Fig. 8 Microscopic features of the spotted and clumpy clotted fabrics in the Xiaoerblak Formation (Cambrian Series 2) of the Sugaitblak section, Tarim Basin, Xinjiang, China. a The spotted clotted fabrics (sd) in Interval I. Some spotted clots are distributed in clusters (clu). The diameter of the clusters is $0.1-0.25 \mathrm{~mm}$. b The clusters (clu) of spotted clots (sd) between laminae, composed of powder crystalline dolomites, in the Interval III. $\mathbf{c}$ In the middle of the Interval $\mathrm{V}$, the recrystallization has turned the clump's micrites to powder crystalline dolomites (th), and the irregular clump was broken into grains, with dolomicrites (mi) between the grains. The places where the dolomicrite have been dissolved were filled with macrocrystalline dolomite (do). d Clumpy clotted fabrics (th) composed of powder crystalline dolomites with distinct dolomicritic outlines, at the bottom of the Interval III. All are photomicrographs of thin sections under plane-polarized light microscope

$0.01 \mathrm{~mm}$. Some microclots are scattered and isolated, at an average distance of more than $0.05 \mathrm{~mm}$, some are gathered in clusters, and are about $0.05 \mathrm{~mm}$ in diameter or larger. The spotted microclots usually have unobvious edges, and are cemented by recrystallized powder and fine crystalline dolomites or spars. The spotted microclots in this formation may have two origins. Firstly, they can be a kind of original microbial microclots formed by microbially-induced precipitation of coccoidal aggregates during their metabolic activities (Riding 2000). Secondly, they may be the remaining parts of previous vermicular or reticular microclots due to recrystallization. Under the second circumstance, the spotted microclots are generally surrounded by fine or medium dolomites, and the trace of dolomicrite left by the original microclots is preserved in the fine or medium dolomite. The spotted fabric is mainly distributed in the Lower Member and the microbial mounds in Interval IV. Its content is limited to only about $10 \%$ due to its small volume and alteration by strong diagenesis. It is not the main fabric of the microbialites in this formation, and often occurs in combination with the vermicular clotted fabric, reticular clotted fabric and laminated clotted fabric.

\subsubsection{Clumpy clotted fabric}

In this microfabric, the microclots are in clumpy shape, are composed of dark dolomicrite, and vary in size, 
ranging in diameter from $0.5 \mathrm{~mm}$ to $1.5 \mathrm{~mm}$. The dolomicrite of the clumpy microclots are mostly recrystallized into powder crystalline dolomite, and only the black edges are preserved. The interspaces between the clumpy microclots aerially account for $20 \%$ to $25 \%$, and have been filled by coarse dolomite (Fig. 8c, d). Some clumpy microclots are isolated and scattered, with smooth edges, and others are in close contact, and can reach $70 \%$ in content, with sharp outlines. The transition from angular irregular clumpy microclots to round grains is present in some thin sections, indicating that some clumps were broken into grains by water actions. This fabric is limited in distribution in the Xiaoerblak Formation, and is not continuous in vertical distribution. Most clumpy microclots have been fragmentized. This kind of fabric occurs in the middle and lower part of Interval $\mathrm{V}$, generally in association with intraclastic dolostones. The content of the clumpy microclots decreases upward the formation, coupling with the increase in the content of intraclastic grains.

\subsection{Laminated fabric}

The laminations generally have two forms: the straight lamination and the undulate lamination. The former is straight and generally formed by inorganic sedimentation. The undulate lamination, is irregularly curved, and is probably formed by precipitation of microbial mats. The laminations discussed below are all microbiogenic laminated fabric.

The laminated fabric refers to the alternation of the dark laminae composed of dolomicrite and the bright laminae composed of medium or coarse dolomite. Examination of all thin sections shows that the laminated fabrics in the Xiaoerblak Formation are all dolomicrites lacking calcified fossils, and are called dolomicritic laminated fabrics. It is noteworthy that the lighter colored rocks between the laminae are composed of clotted thrombolitic dolostone of powder to medium crystalline dolomite. The dolomicritic laminae are generally composed of dolomicrite, dark in color, and are wavy in shape. Based on the features of the dolomicritic laminae, the laminated fabrics are divided into two subtypes, the wavy laminated fabric, and the compound laminated fabric (Fig. 9). The compound lamination is the main type, and can account for more than $70 \%$.

The wavy laminated fabric consists of thin darkcolored dolomicritic laminae and the alternating lightercolored thrombolitic layers that are composed of powder, fine or medium crystalline dolomite (Fig. 10a, b, c). The dark laminae vertically contact with each other, some being imbricate, with thrombolitic fabrics filling the bright layers between the dolomicritic laminae. Comparing with the compound laminated fabric, the laminae in the wavy laminated fabric tend to be more curved with a wide range but mostly have poor continuity, with a length of less than $2 \mathrm{~mm}$ laterally. The thickness of a single dark lamina is less than $0.2 \mathrm{~mm}$, while the clotted layers vary greatly in thickness, and are generally thicker than the dark laminae, ranging from $0.5 \mathrm{~mm}$ to 2 $\mathrm{mm}$. There are numerous irregular and elongated pores filled with microspars or coarse dolomite in the bright layers or even lying near the dark laminae, which can be formed from dissolution and crystallization. The wavy laminated fabric is a rare type in the Xiaoerblak
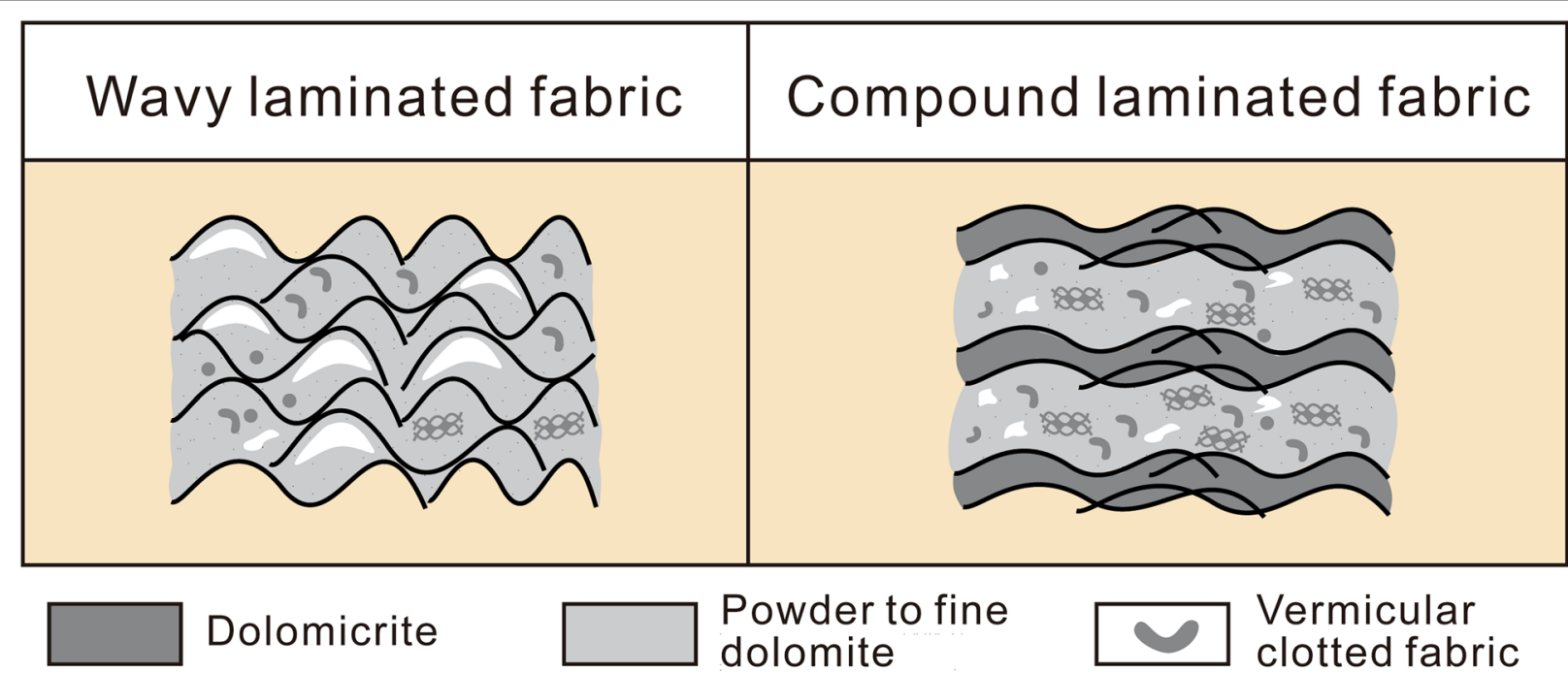

Powder to fine dolomite

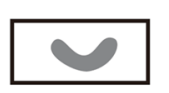

Vermicular clotted fabric Spotted clotted fabric $\nabla \curvearrowleft$ Filled pores

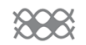
Reticular
clotted fabric

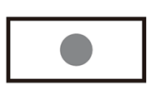

Fig. 9 Subtypes of laminated fabrics in the Xiaoerblak Formation of the Sugaitblak section, Tarim Basin, Xinjiang, China 

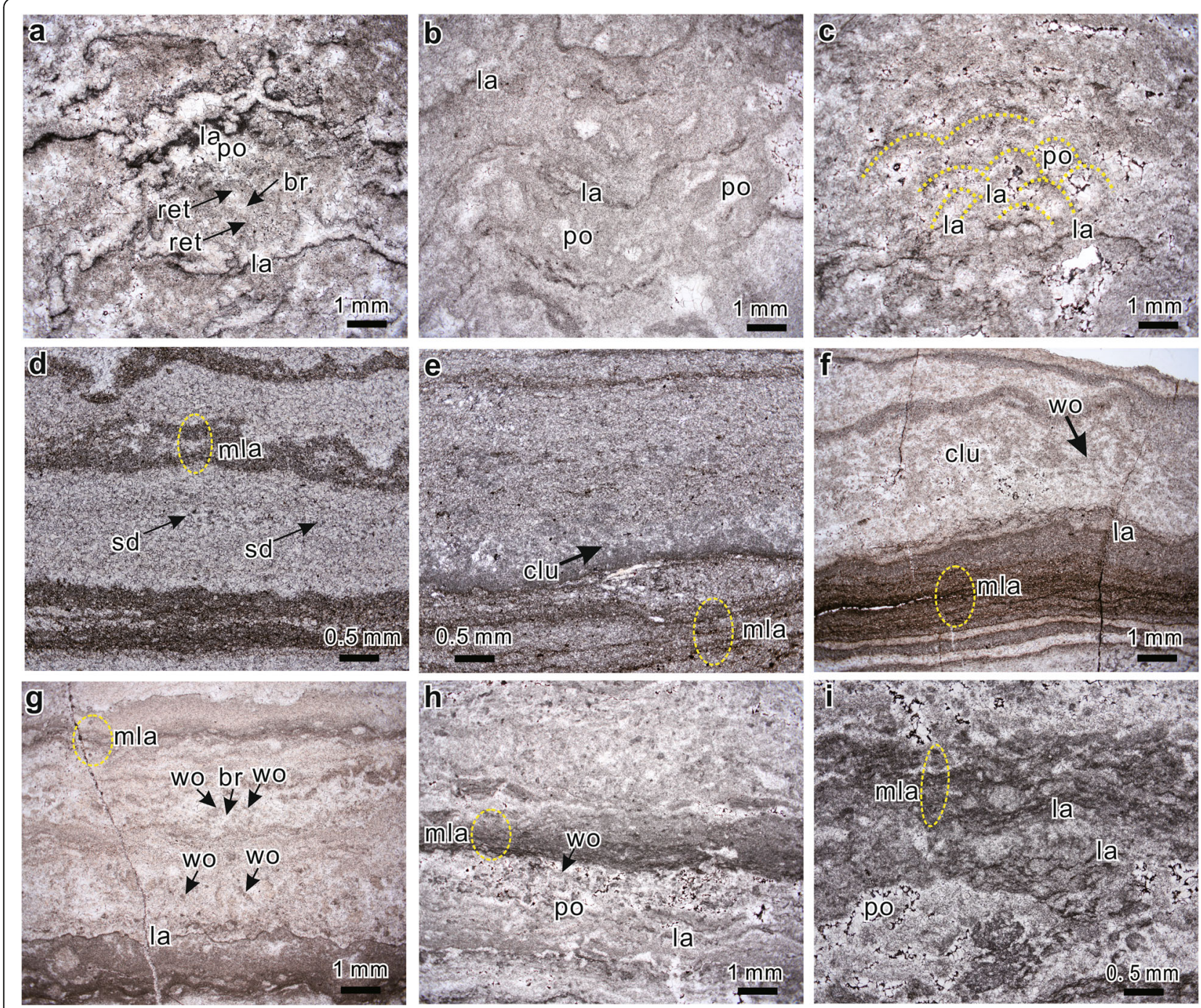

Fig. 10 Microscopic features of the laminated fabrics in the Xiaoerblak Formation (Cambrian Series 2) of the Sugaitblak section, Tarim Basin Xinjiang, China. a, b Wavy laminated fabric consisting of wavy dark-colored dolomicritic laminae (la) and the lighter-colored thrombolitic rock consisting of reticular clotted fabrics (ret) and filled meshes (br) between the laminae, with irregular pores (po), in the lower part of Interval V. c The imbricated wavy laminated fabric consisting of dark-colored dolomicritic wavy laminae (la) and the lighter-colored thrombolitic layers between the laminae, with pores (po), in the lower part of Interval V. $\mathbf{d}$-f The compound laminated fabric consisting of dark-colored dolomicritic lamina (la) or laminae (mla) and the lighter-colored layers with spotted clotted fabric (sd, clu) and vermicular clotted fabric (wo), in the Interval III. g-i The compound laminated fabric consisting of dark-colored dolomicritic laminae ( $\mathrm{mla}$ ) and the lighter-colored thrombolitic layers, with vermicular clotted fabric (wo), pores (po) and filled meshes (br), in the Interval V. All are photomicrographs of thin sections under plane-polarized light microscope

Formation, and mainly occurs in the bottom of the Interval $\mathrm{V}$ with low content.

The compound laminated fabric (Fig. 10d-i) consists of dark-colored dolomicritic laminae and the alternative lighter-colored thrombolitic layers between the laminae. The dark lamina can be considered as a kind of aggregation of several singular thin dark laminae. The dark laminae are slightly curved, $0.8-1.2 \mathrm{~mm}$ in thickness with single lamina less than $0.1 \mathrm{~mm}$ in thickness, usually thicker than the dark laminae in the wavy laminated fabric, and have better continuity. The bright layers are generally greater than $2 \mathrm{~mm}$ in thickness, and are composed of powder to fine crystalline dolomites, sometimes containing reticular, vermicular or spotted clotted fabric, and having bright spots composed of microspar and fine dolomite. There are also voids in the dark laminae, which are usually filled with powder crystalline dolomites. It is noted that the bright layers always contain more pores than the dark laminae, indicating the difference between biomineralization and inorganic mineralization. The compound laminated fabric is the dominated laminated type in the Xiaoerblak Formation, and mainly occurs in the Interval V, and in the Interval III. 


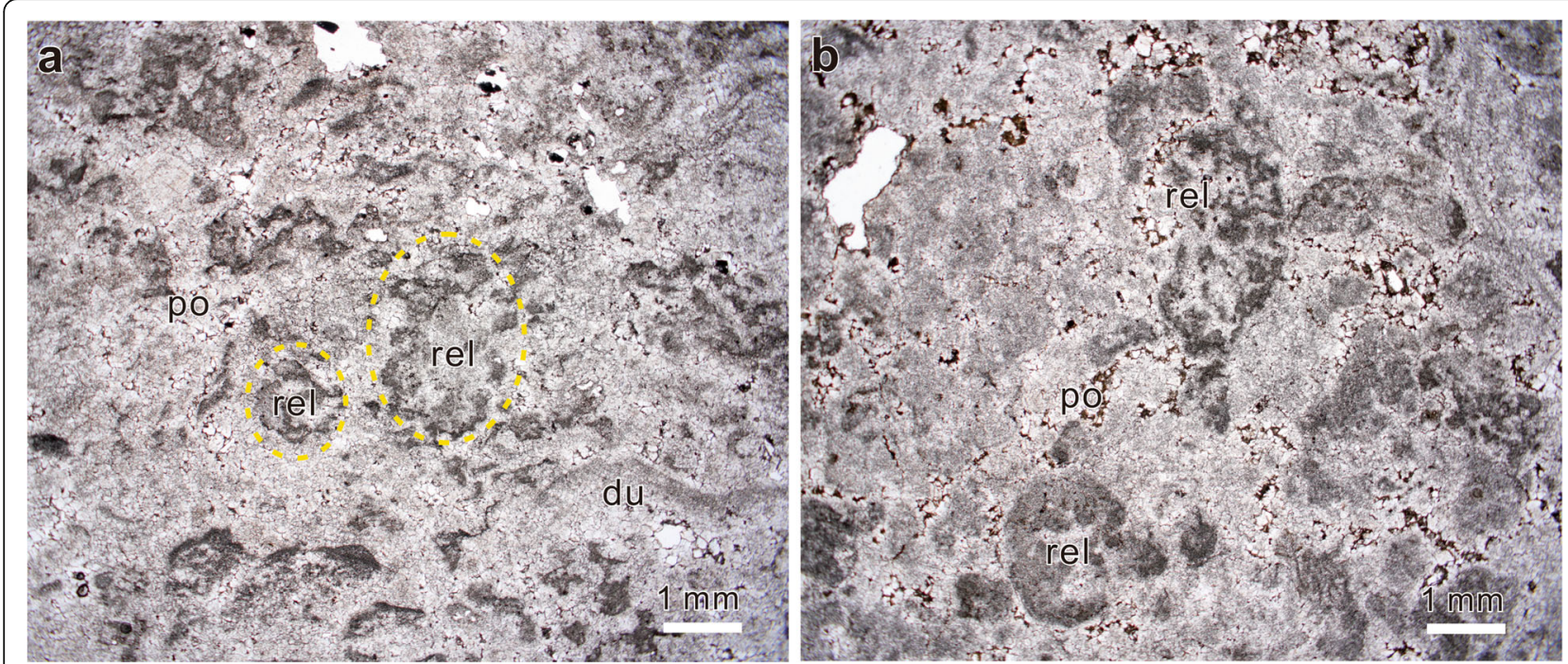

Fig. 11 Microscopic features of the skeletal fabric in the Xiaoerblak Formation of the Sugaitblak section, Tarim Basin, Xinjiang, China. a, b Renalcis (rel) skeletons with biological fragments (du) and pores (po), at the upper part of Interval $\mathrm{V}$. Both are photomicrographs of thin sections under polarized light microscope

\subsection{Skeletal fabric}

This microfabric has a framework consisting of Renalcis skeletons (Fig. 11a, b). The Renalcis skeletons are sparsely and irregularly distributed, with a size of $(0.5-1$ $\mathrm{mm}) \times(0.5-2 \mathrm{~mm})$, and consist of a string of hollow spherical chambers. Each chamber has a flower-like cavity, which is generally filled with coarse dolomite. The high variability in size demonstrates that the chamber is not an individual cell but a colony of numerous cells. The dark wall of the cavity comprises dense dolomicrite with distinct smooth exterior and crinkled blurred internal surface which is presumably inheritance of gelatinous colony morphology. To date, the systematic position of Renalcis is still uncertain. Some researchers considered it a calcified cyanobacterium related to chroococcaceae which experienced carbonate diagenesis involving obliteration of cell morphology (Hofmann 1975; Pratt 1984). Others suggested that it is formed by bacteria-induced precipitation (Stephens and Sumner 2002). This fabric is distributed in the upper part of Interval V. Since it contains fragments of Renalcis skeletons, and the overlying and underlying layers develop intraclastic fabric, this fabric is likely formed in shallow subtidal zone with relatively high water energy.

\section{Discussion}

\subsection{Diagenesis models of microbialite fabrics}

Microbialite fabrics are controlled by both microbial communities and diagenesis. The microbe composition determines the features of the original fabrics and the original pores, which both suffer the alteration by diagenesis. Diagenesis determines the final fabrics visibly in thin sections. Examination of the thin sections shows that the microbialites of the Xiaoerblak Formation have undergone at least three diagenetic events, i.e., penecontemporaneous dolomitization, recrystallization and dissolution.

The penecontemporaneous dolomitization began the earliest, changing the calcite and aragonite limestones into dolomites. Based on the thin sections, the microbialite fabrics composed of micrites are mostly preserved, and are now composed of dolomicrite. The fabricpreserving dolomitization was termed as mimic dolomitization, which did not destroy the original fabrics of the precursor limestones (Sibley 1980, 1982). The mimic dolomitization is a common phenomenon occurring extensively in strata during different periods. During the process of mimic dolomitization, precursor micrites provided abundant nucleation sites to make the dolomitization performed rapidly, and the resultant dolomite retains the original fabrics (Bullen and Sibley 1984). The crystal size is the main factor to determine whether the dolomitization is mimic or not, since smaller crystals are more likely to provide sufficient dolomite nuclei for mimic replacement (Sibley 2003). Besides, some authors considered that the calcite with high magnesium tends to retain primary fabrics, but the calcite with low magnesium tends to result in fabrics-destroying dolomitization (Murray and Lucia 1967). And low temperature was considered to promote fabric-preserving dolomitization than high temperature (Machel 2004).

The recrystallization occurred during the whole diagenetic stage. According to observation of the thin sections, the recrystallization degree of the Lower Member 
is higher than that of the Upper Member. Due to this process, the original crystals gradually became larger: the dolomicrite changed into powder or even mediumcoarse crystalline dolomites, which makes it difficult to distinguish the changed fabrics from the surrounding cements. The recrystallization in this formation has strong heterogeneity, and areas of different recrystallization intensities can be observed on a single section, which can be exampled by a thin section from the microbial mound in the Interval IV (Fig. 12a). Recrystallization firstly affected the edge of the microclots, then the inner part, and lastly the center. Thus, in most cases, the center of the microclots consists of dolomicrite, and their edges can be powder or fine crystalline dolomite, depending on the effects degree of recrystallization. Alteration by strong recrystallization has changed most part of the microclots, leaving their central parts as small black dolomicritic spots (Fig. 12c). As to the reticular microclots, with the development of the recrystallization, crystals of the meshes and those comprising the fillings became more and more similar (Fig. 12b), and finally only the original dolomicrite at the intersection remained. The laminated fabric in the Interval I has been severely affected by recrystallization, and consists of powder crystalline dolomites, being thin, sparse, laterally discontinuous. The rock between the laminae is
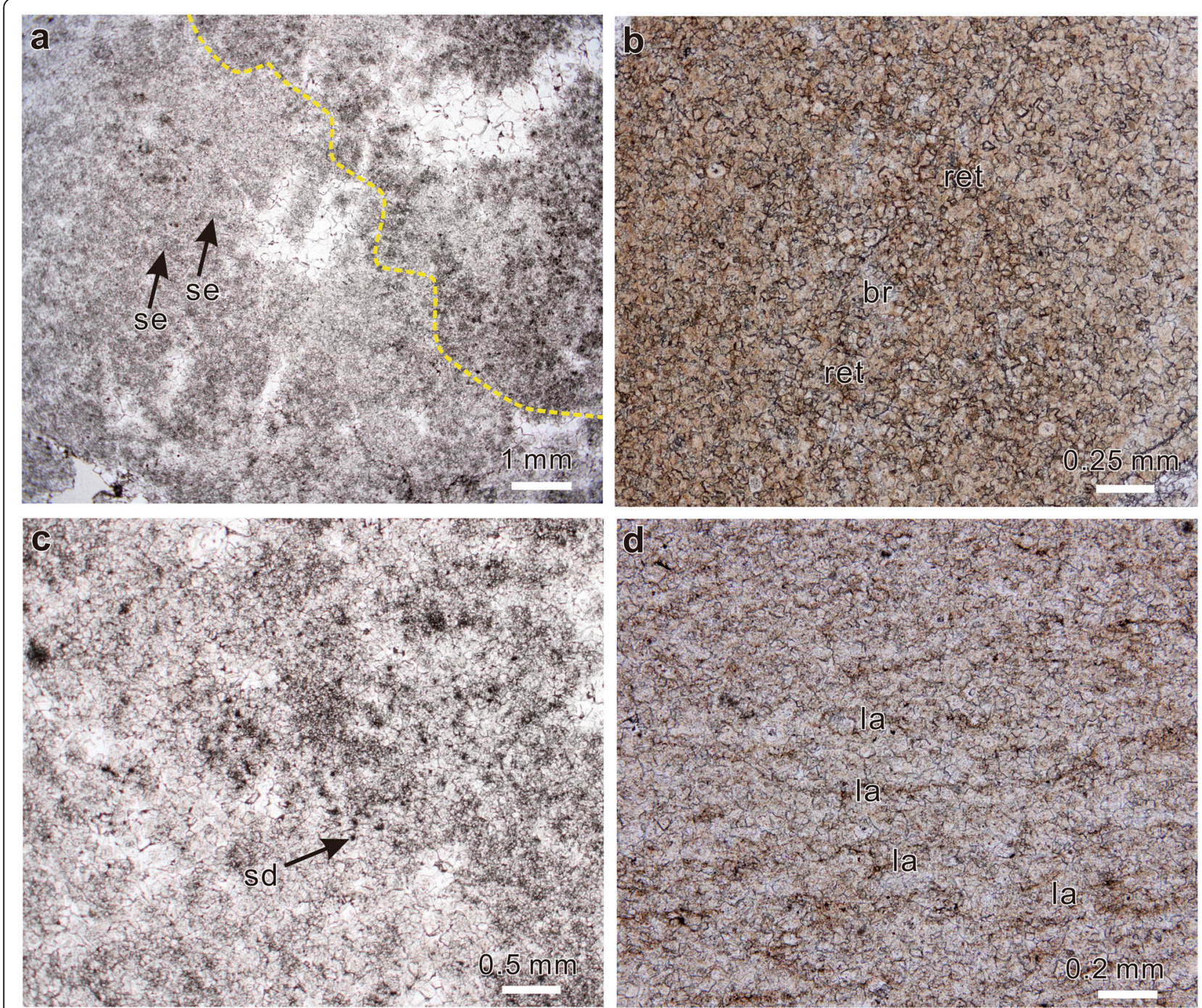

Fig. 12 Diagenetic characteristics of the microbialites of the Xiaoerblak Formation of the Sugaitblak section, Tarim Basin, Xinjiang, China. a Due to the recrystallization, the size of dolomite in the left is larger than that in the right (separated by the yellow dashed line), in microbial mound of the Interval IV. The reticular fabric remains (se) can be seen. $\mathbf{b}$ The recrystallization is stronger than that in $\mathbf{a}$. The reticular fabric (ret) is hard to observe, in the Interval II. c The recrystallization turned the vermicular fabrics into spotted fabrics (sd), in Interval IV. d The residual single lamina (la) caused by recrystallization, in the upper part of Interval I, at the bottom of Interval II. All are photomicrographs of thin sections under planepolarized light microscope 
composed of fine dolomites, with some dolomicrite left between the fine dolomite, and the original fabric type is difficult to identify (Fig. 12d).

This formation has experienced three kinds of dissolution: atmospheric water dissolution in the epidiagenetic stage, hydrothermal dissolution in the burial stage and organic acid dissolution (Shen et al. 2016; Bai et al. 2018), which have been studied by previous researchers (Shen et al. 2016) in details, hence will not be discussed here. The dissolution events led to the following two results: firstly, they destroyed the original fabrics of the microbialites to different degrees, and secondly, they have improved the quality of the reservoirs. The evolution of the original fabrics of the Xiaoerblak Formation controlled by diagenesis is summarized in Fig. 13.

On the whole, the Lower Member of this formation has been influenced more by the diagenesis than the Upper Member. For Intervals I and II, the laminae are sparse and discontinuous rather than dense and continuous, and the microclots are composed of fine or medium dolomite rather than dolomicrite, both indicating strong recrystallization. The development of the fenestral structure indicates strong dissolution during the epidiagenetic stage. Interval III is the only part of this formation that contains limestones, and is inferred to have a diagenetic history different from the Intervals I and II. In this interval the content of the clotted fabric decreased, and the laminated fabric is abundant, mainly being single lamination with good continuity and good preservation. However, the reticular fabric and vermicular fabric between the laminae have been strongly damaged, leaving spotted fabrics (Figs. 8b, 10d). The lower part of Interval IV and Interval V are mainly reticular fabric and vermicular fabric, only partially affected by recrystallization, and the original fabrics are mostly recognizable. Although the thrombolites between the laminae contain some dissolution pores, the recrystallization is weaker, and the lamination is in good preservation, the laminated types are the most abundant in the formation, and the reticular fabric and vermicular fabric are well preserved in some places (Fig. 10).

\subsection{Formation environments}

The original structure of microbialites can indicate some aspects of their formation environments, such as water

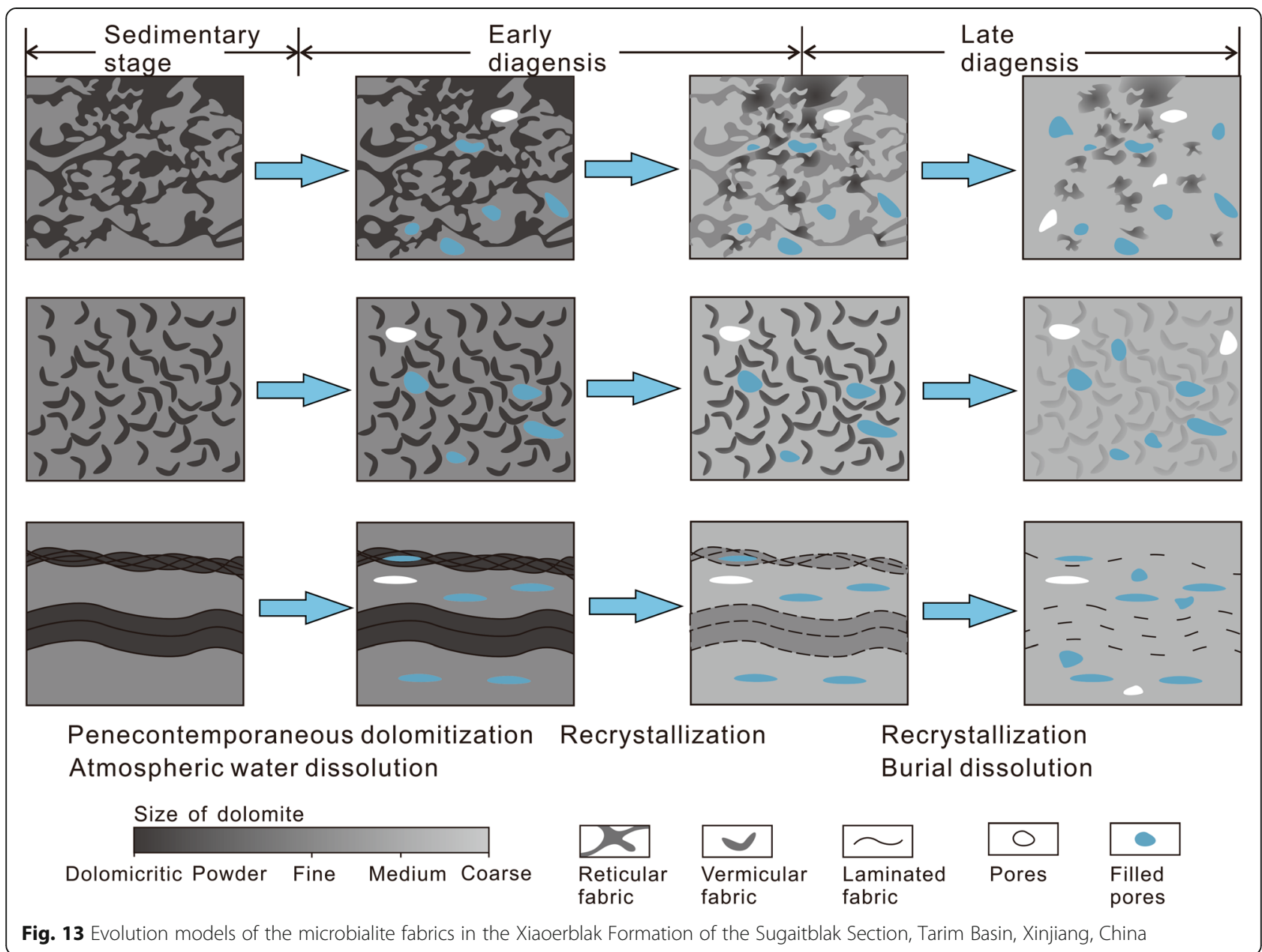


depth and hydrodynamic intensity. It is thought that tabular laminated stromatolites form near the average high tide level or subtidal zone with weak hydrodynamic condition, while domal and columnar stromatolites form in intertidal zone of high water energy, and dendritic thrombolites form at lagoons of evaporation platform (Jahnert and Collins 2012; Mettraux et al. 2015). Some researchers analyzed the formational environments of microbialites according to their mesostructures, but not based on the fabrics at microscale, since the relationship between the fabrics and their formation environments have not been determined.

Previous researchers believed (Feng et al. 2002, 2006) that the entire Xiaoerblak Formation was deposited on a sedimentary platform. Bai et al. (2018) thought that the entire Xiaoerblak Formation in Aksu area was deposited on the transition from a carbonate slope to a rimmed carbonate platform, and the thrombolite reef and Epiphyton reef in the Upper Member mainly formed at platform margin. Zheng et al. (2019) and others believed that the Xiaoerblak Formation in the Aksu area belonged to a system of shoals, tidal flats, and mounds at a ramp.

In this study it was found that the Lower Member of this formation is mainly composed of dolomicrite and powder crystalline dolomite, without debris or grains, representing a low energy marine environment. From the middle of Interval $\mathrm{V}$, the intraclastic fabric and skeletal fabric began to increase, both of which are signs of higher water energy. So, the whole Xiaoerblak Formation experienced a transition from a limited platform to an open platform.

Interval I is thin-bedded and is composed of dolomicrite. It has laminated fabric and birdseye structures in the lower part, representing intertidal to supratidal environments, but these structures become sparse in the upper part. Since the upper part lacks evidence of tidal environments, it indicates the deepening of the water.

Interval II is mainly thrombolites, with inconspicuous thin beds, which may be formed from alteration of thin-bedded structures. The lower part of this interval contains laterally elongate dissolution pores of $\mathrm{cm}$ size, which may be formed from dissolution of previous birdseye structures. So this part originally contains birdeyes, and was formed in intertidal to supratidal flat environments. The upper part of this interval lacks birdeye structures, but has reticular fabric and laminated fabric, probably representing low energy subtidal environments. Interval III is composed of $\mathrm{mm}$-scale microbial laminae, representing low energy intertidal to supratidal environments. Interval IV consists of massive mounds and the thin-bedded dolostones between the mounds. The mounds are composed of thrombolites and range from $6 \mathrm{~m}$ to $20 \mathrm{~m}$ in height, which indicates a subtidal depth of more than 20 $\mathrm{m}$. Since there is no evidence of wave action, the top of the highest mound should be below the fairweather wave base, which is about $15 \mathrm{~m}$ for open seas but less than $15 \mathrm{~m}$ for restricted waters. Thus this interval is probably formed at a water depth of $>35 \mathrm{~m}$. The lower part of Interval V is reticular thrombolites, without evidence of wave action, indicating a low energy subtidal environment. The upper part of this interval contains laminated and skeletal fabrics in an ascending order, with some trilobite fossils. The intraclasts and skeletal fabrics represent a high energy environment, and the fossils indicate an open marine environment. So, this interval is a shallowing-up sequence.

In summary, the Xiaoerblak Formation formed in three kinds of environments: Intervals I, II and III mainly on a restricted tidal flat, the Interval IV and the lower part of the Interval $\mathrm{V}$ in a restricted deep subtidal environment, and the upper part of Interval $\mathrm{V}$ in a shallowing-up open subtidal environment (Fig. 14). The
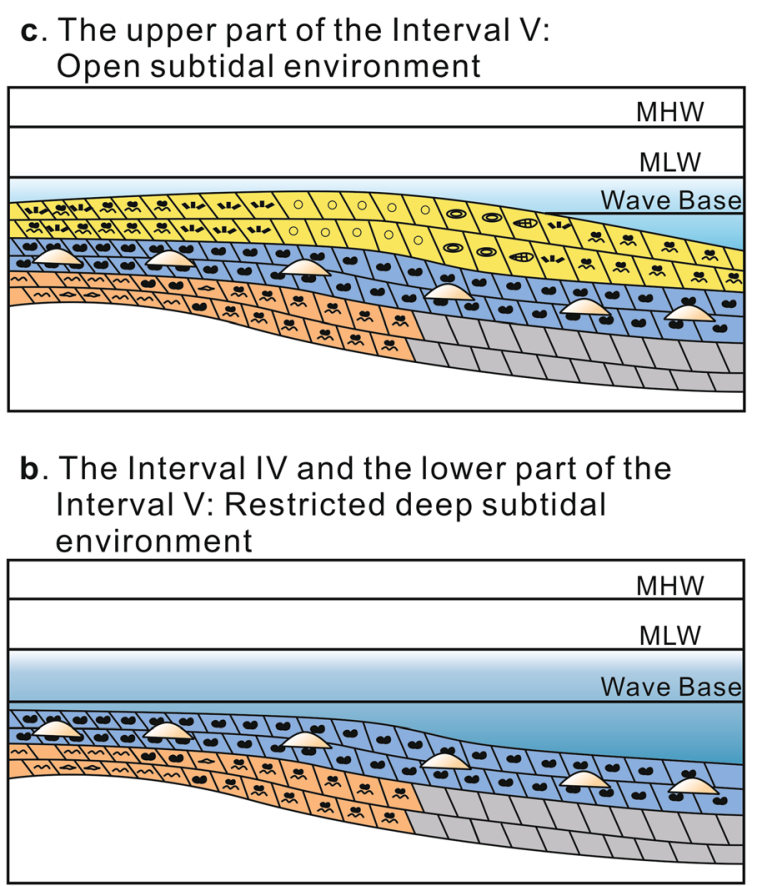

a. The Intervals I, II and III: Restricted tidal flat
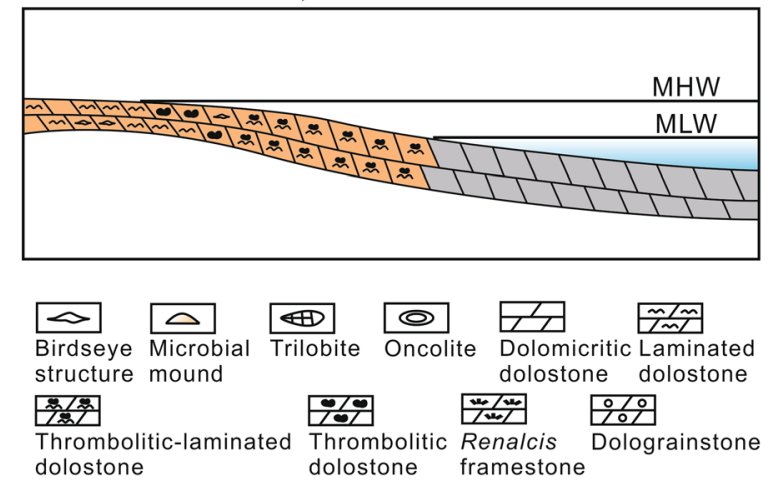

Fig. 14 Model of microbialites forming environment of the Xiaoerblak Formation of the Sugaitblak section, Tarim Basin, Xinjiang, China. MLW: Mean low water; MHW: Mean high water 
sedimentary environments of the Xiaoerblak Formation seem to impose little restrictions to microbialites which occur in a wide range of environments from tidal flat to deep subtidal zone. Except for the Renalcis framestone with skeletal fabrics that formed in high energy environments, the other three main types of microbialites, i.e., laminites, thrombolites, and thrombolitic laminite, can develop both in tidal flat and deep subtidal zone, even in the shallow open subtidal environment. There is no obvious difference in the depth and energy of water between the thrombolites and laminites. The common occurrence of the thrombolitic laminites shows that the thrombolites and laminites formed under similar conditions. It could be the types of organisms that determined the development of laminites. But it is still hard to distinguish microorganisms from the rocks intensively influenced by diagenesis. In terms of specific fabrics of the microbialites, the reticular clotted fabric and laminated fabric are the two most abundant types and are widely distributed in all of the three environments. The vermicular clotted fabric tends to mainly occur in the Upper Member, especially in the microbial mounds representing a deep-water environment.

\section{Conclusions}

(1) The Xiaoerblak Formation (Cambrian Stage 3 and lower Stage 4) of the Sugaitblak section is composed of bedded or mound-like microbial dolostones. The mounds are composed of thrombolite dolostones, and the bedded microbialite dolostones include thrombolites, laminites, thrombolitic laminites and some calcimicrobial framestones. The main fabrics include clotted, laminated, and some skeletal fabrics.

(2) The clotted fabric can be divided into four subtypes: vermicular clotted fabric, reticular clotted fabric, spotted clotted fabric and clumpy clotted fabric. The reticular clotted fabric is the dominant subtype, and mainly occurs in the lower part of Interval II, Interval IV and lower part of Interval V. The laminated fabric can be divided into wavy laminated fabric and compound laminated fabric. The compound laminated fabric is the dominating subtype, and is mainly present in Interval V.

(3) The fabrics of the microbialites of the Xiaoerblak Formation are controlled by the microbial communities and the diagenesis. The original microfabrics have been affected by dolomitization, recrystallization and dissolution. Dolomitization mainly occurred in the epidiagenetic stage, and is in mimic mode, without severe affection on the original microfabrics. The recrystallization and dissolution have severe affection on the original fabrics. It seems that the laminated fabric has the strongest resistance to diagenesis, secondly the clotted fabric.

(4) The thrombolites are mainly in Interval II, Interval IV, and the lower part of Interval V. The laminites mainly occur in Interval I. The thrombolitic laminites mainly develop in Interval III and upper part of Interval $\mathrm{V}$, and the Renalcis framestones are in upper part of Interval V. Intervals I, II, and III are mainly formed on tidal flats, and Interval IV and the lower part of Interval $\mathrm{V}$ are formed in deeper subtidal water. The upper part of Interval $\mathrm{V}$ formed in shallowing-up subtidal water.

\section{Abbreviations}

bir: Birdseye; br: Fillings in meshes; CCM: Cyanobacteria calcification mechanism; clu: Cluster; do: Macrocrystalline dolomite; du: Biological fragment; Int:: Rocks between the mounds (Int.); la: Lamina; MHW: Mean high water; mi: Dolomicrite; mla: Laminae; MLW: Mean low water; po: Pore; PPL: Plane polarized light; rel: Renalcis; ret.: Reticular microclot; sd: Spotted microclot; se: Fabric remains; th: Clumpy microclot; tr: Trilobite; wo: Vermicular microclot; XPL: Cross polarized light

\section{Acknowledgements}

We thank Li-Jing Zheng, Yue-Yang Zhang and Zi-Wen Jiang for their contributions in the measurement of field profiles during the research. We are grateful to Professor Robert Riding for revising the original manuscript. Also we would like to thank the two anonymous reviewers for invaluable comments and affirmations.

\section{Authors' contributions}

YSW and WQP are responsible for the design and guidance of the project. YSW performed the measurement of field profiles and sampling. YL and YSW are in charge of microstructure research. GY, CHS and HXJ analyzed mesoand macrostructure features of the samples. $Y L$ is a major contributor in writing the manuscript. YSW and HXJ reviewed and revised the manuscript. All authors read and approved the final manuscript.

\section{Funding}

This study was supported by the National Natural Science Foundation of China (Grant No. 41972320), National Major Science and Technology Projects of China (Grant No. 2016ZX05004004-005) and the Strategic Priority Research Program (B) of Chinese Academy of Sciences (Grant No. XDB26000000).

\section{Competing interests}

The authors declare that they have no competing interests.

\section{Author details \\ ${ }^{1}$ Key Laboratory of Cenozoic Geology and Environment, Institute of Geology and Geophysics, Chinese Academy of Sciences, Beijing 100029, China. ${ }^{2}$ Innovation Academy for Earth Science, Chinese Academy of Sciences, Beijin 100029, China. ${ }^{3}$ University of Chinese Academy of Sciences, Beijing 100049, China. ${ }^{4}$ Hebei GEO University, Shijiazhuang 050031, China. ${ }^{5}$ Research Institute of Petroleum Exploration and Development, Tarim Oilfield Company, PetroChina, Korla, Xinjiang, Uygur Autonomous Region 841000, China.}

Received: 21 July 2020 Accepted: 21 December 2020

Published online: 13 January 2021

\section{References}

Adachi, N., Y. Ezaki, and J.B. Liu. 2011. Early Ordovician shift in reef construction from microbial to metazoan reefs. Palaios 26 (2): 106-114.

Aitken, J.D. 1967. Classification and environmental significance of cryptalgal limestones and dolomites, with illustrations from the Cambrian and Ordovician of southwestern Alberta. Journal of Sedimentary Petrology 37 (4): 1163-1178. 
Bai, Y., P. Luo, W. Liu, X.F. Zhai, and C.M. Zhou. 2018. Characteristics and main controlling factors of microbial carbonate reservoir: A case study of upper member of lower Cambrian Xiaoerbulake formation in Akesu area, Tarim Basin. China Petroleum Exploration 23 (4): 95-106 (in Chinese with English abstract).

Braga, J.C., J.M. Martin, and R. Riding. 1995. Controls on microbial dome fabric development along a carbonate-siliciclastic shelf-basin transect, Miocene, SE Spain. Palaios 10 (4): 347-361.

Bullen, S.B., and D.F. Sibley. 1984. Dolomite selectivity and mimic replacement. Geology 12 (11): 655-658.

Burne, R.V., and L.S. Moore. 1987. Microbialites: Organosedimentary deposits of benthic microbial communities. Palaios 2 (3): 241-254.

Chen, J.T., J.H. Lee, and J. Woo. 2014. Formative mechanisms, depositional processes, and geological implications of Furongian (late Cambrian) reefs in the North China platform. Palaeogeography, Palaeoclimatology, Palaeoecology 414: 246-259.

Du, R.L. 1992. The Paleobiology and historical geology of the Precambrian, $1-$ 193. Beijing: Geological Publishing House (in Chinese).

Feng, Z.Z., Z.D. Bao, M.B. Wu, Z.K. Jin, and X.Z. Shi. 2006. Lithofacies palaeogeography of the Cambrian in Tarim area. Journal of Palaeogeography (Chinese Edition) 8 (4): 427-439 (in Chinese with English abstract).

Feng, Z.Z., Y.M. Peng, Z.K. Jin, and Z.D. Bao. 2002. Lithofacies palaeogeography of the early Cambrian in China. Journal of Palaeogeography (Chinese Edition) 4 (1): 1-12 (in Chinese with English abstract).

Friedman, G.M., A.J. Amiel, M. Braun, and D.S. Miller. 1973. Generation of carbonate particles and laminites in algal mats - Example from seamarginal hypersaline pool, Gulf of Aqaba, Red Sea. AAPG Bulletin 57 (3): 541-557.

Glumac, B., and K.R. Walker. 1997. Selective dolomitization of Cambrian microbial carbonate deposits: A key to mechanisms and environments of origin. Palaios 12 (2): 98-110.

Golubic, S. 1973. The relationship between blue-green algae and carbonate deposits. In The Biology of Blue-Green Algae, ed. N.G. Carr and B.A. Whitton, 434-472. Oxford: Blackwell.

Han, Z.Z., J.T. Chen, N.J. Chi, Z.P. Wang, R.C. Yang, and A.P. Fan. 2009. Microbial carbonates: A review and perspectives. Marine Geology and Quaternary Geology 29 (4): 29-38 (in Chinese with English abstract).

Harwood Theisen, C., and D.Y. Sumner. 2016. Thrombolite fabrics and origins: Influences of diverse microbial and metazoan processes on Cambrian thrombolite variability in the Great Basin, California and Nevada. Sedimentology 63 (7): 2217-2252.

Hofmann, H.J. 1975. Stratiform Precambrian stromatolites, Belcher Islands, Canada: Relations between silicified microfossils and microstructure. American Journal of Science 275 (10): 1121-1132.

Huang, Q.Y., S.Y. Hu, W.Q. Pan, W. Liu, Y.L. Chi, K. Wang, S.Y. Shi, and Q. Liu. 2016. Sedimentary characteristics of intra-platform microbial mounds and their controlling effects on the development of reservoirs: A case study of the lower Cambrian Xiaoerbulake formation in the KepingBachu area, Tarim Basin. Natural Gas Industry 36 (6): 21-29 (in Chinese with English abstract).

Huang, Z.B., L.J. Liu, H.J. Yang, Y.S. Wu, Z.L. Yang, R. Zhao, Z.Y. Xiao, and W.Q. Pan. 2017. The spatial-temporal distribution of paleocommunities on the Cambrian platform of the Tarim block and its stratigraphic significances. Journal of Stratigraphy 41 (1): 1-16 (in Chinese with English abstract).

Jahnert, R.J., and L.B. Collins. 2012. Characteristics, distribution and morphogenesis of subtidal microbial systems in Shark Bay, Australia. Marine Geology 303-306: 115-136.

James, N.P., and D.I. Gravestock. 1990. Lower Cambrian shelf and shelf margin buildups, Flinders ranges, South Australia. Sedimentology 37 (3): 455-480.

Kiessling, W. 2009. Geologic and biologic controls on the evolution of reefs. Annual Review of Ecology, Evolution, and Systematics 40 (1): 173-192.

Lee, J.H., J.T. Chen, S.J. Choh, D.J. Lee, Z.Z. Han, and S.K. Chough. 2014. Furongian (late Cambrian) sponge-microbial maze-like reefs in the North China platform. Palaios 29 (1): 27-37.

Lee, J.H., J.T. Chen, and S.K. Chough. 2010. Paleoenvironmental implications of an extensive maceriate microbialite bed in the Furongian
Chaomidian formation, Shandong Province, China. Palaeogeography, Palaeoclimatology, Palaeoecology 297 (3-4): 621-632.

Li, P.W., P. Luo, J.M. Song, T.F. Jin, and G.Q. Wang. 2015. Characteristics and main controlling factors of microbial carbonate reservoirs: A case study of upper Sinian-lower Cambrian in the northwestern margin of Tarim Basin. Acta Petrolei Sinica 36 (9): 1074-1089 (in Chinese with English abstract).

Machel, H.G. 2004. Concepts and models of dolomitization: A critical reappraisal. In: The Geometry and Petrogenesis of Dolomite Hydrocarbon Reservoirs, eds. C.J.R. Braithwaite, G. Rizzi, and G. Darke. Geological Society, London, Special Publications, 235: 7-63.

Mettraux, M., P. Homewood, C. Dos Anjos, M. Erthal, R. Lima, N. Matsuda, A. Souza, and S. Al Balushi. 2015. Microbial communities and their primary to early diagenetic mineral phases: The record from Neoproterozoic microbialites of Qarn Alam, Oman. In: Conference on Microbial Carbonates in Space and Time: Implications for Global Exploration and Production. Geological Society, London, Special Publications, 418: 123-154.

Monty, C.L.V. 1976. The origin and development of cryptalgal fabrics. In: Developments in Sedimentology, volume 20, ed. M.R. Walter, pp. 193-249. New York: Elsevier.

Murray, R.C., and F.J. Lucia. 1967. Cause and control of dolomite distribution by rock selectivity. GSA Bulletin 78 (1): 21-35.

Pratt, B.R. 1984. Epiphyton and Renalcis - Diagenetic microfossils from calcification of coccoid blue-green algae. Journal of Sedimentary Petrology 54 (3): 948-971.

Riding, R. 1991. Calcareous Algae and Stromatolites, ed. R. Riding, pp. 21-51. Heidelberg: Springer.

Riding, R. 2000. Microbial carbonates: The geological record of calcified bacterial-algal mats and biofilms. Sedimentology 47 (s1): 179-214.

Riding, R. 2006. Cyanobacterial calcification, carbon dioxide concentrating mechanisms, and Proterozoic-Cambrian changes in atmospheric composition. Geobiology 4 (4): 299-316.

Riding, R. 2011. Microbialites, stromatolites, and thrombolites. In Encyclopedia of Geobiology, encyclopedia of earth science series, ed. J. Reitner and V. Thiel, 635-654. Heidelberg: Springer.

Riding, R. 2012. A hard life for cyanobacteria. Science 336: 427-428.

Rowland, S.M., and R.A. Gangloff. 1988. Structure and paleoecology of lower Cambrian reefs. Palaios 3 (2): 111-135.

Shapiro, R.S. 2000. A comment on the systematic confusion of thrombolites. Palaios 15 (2): 166-169.

Shapiro, R.S. 2004. Neoproterozoic-Cambrian microbialite record. The Paleontological Society Papers 10: 5-16.

Shen, A.J., J.F. Zheng, Y.Q. Chen, X.F. Ni, and L.L. Huang. 2016. Characteristics, origin and distribution of dolomite reservoirs in lowermiddle Cambrian, Tarim Basin, NW China. Petroleum Exploration and Development 43 (3): 340-349 (in Chinese with English abstract).

Sibley, D.F. 1980. Climatic control of dolomitization, Seroe Domi formation (Pliocene), Bonaire, N.a. in: Concepts and Models of Dolomitization. SEPM Special Publications 28: 247-258.

Sibley, D.F. 1982. The origin of common dolomite fabrics: Clues from the Pliocene. Journal of Sedimentary Petrology 52 (4): 1087-1100.

Sibley, D.F. 2003. Dolomite textures. In: Encyclopedia of Sediments and Sedimentary Rocks, pp. 231-234. Dordrecht: Springer.

Song, J.M., P. Luo, S.S. Yang, D. Yang, C.M. Zhou, P.W. Li, and X.F. Zhai. 2014. Reservoirs of lower Cambrian microbial carbonates, Tarim Basin, NW China. Petroleum Exploration and Development 41 (4): 404-413 (in Chinese with English abstract).

Song, J.M., P. Luo, S.S. Yang, X.F. Zhai, G. Zhou, and P.P. Lu. 2012. Carbonate rock microbial construction of the lower Cambrian Xiaoerblak formation in Sugaitblak area, Tarim Basin. Journal of Palaeogeography (Chinese Edition) 14 (3): 341-354 (in Chinese with English abstract).

Stephens, N.P., and D.Y. Sumner. 2002. Renalcids as fossilized biofilm clusters. Palaios 17 (3): 225-236.

Turner, E.C., N.P. James, and G.M. Narbonne. 1997. Growth dynamics of Neoproterozoic calcimicrobial reefs, Mackenzie Mountains, Northwest Canada. Journal of Sedimentary Research 67 (3): 437-450.

Wang, J., R.L. Zhuang, K.T. Lao, and G.H. Long. 1990. Division and geological implications of calcareous algal morphological groups and 
environmental zones in the lower Cambrian Qingxudong formation, Huayuan District, western Hunan. Sedimentary Facies and Palaeogeography 10 (3): 9-19 (in Chinese with English abstract).

Wang, J.P., Y. Li, L. Cheng, X.W. Zeng, and G. Wang. 2014. Paleozoic reefs and their paleogeological controls in South China block. Acta Palaeontologica Sinica 53 (1): 121-131 (in Chinese with English abstract).

Wood, R. 1998. The ecological evolution of reefs. Annual Review of Ecology and Systematics 29 (1): 179-206.

Wood, R. 1999. Reef Evolution, 33-59. Oxford: Oxford University Press.

Wu, Y.S., H.X. Jiang, G.L. Yu, and L.J. Liu. 2018. Conceptions of microbialites and origin of the Permian-Triassic boundary microbialites from Laolongdong, Chongqing, China. Journal of Palaeogeography (Chinese Edition) 20 (5): 737-775 (in Chinese with English abstract).

Xiong, Y.X., Y.Q. Chen, B.Z. Guan, L.P. Deng, X.F. Ni, and R. Xiong. 2015. Distribution of northern platform margin and implications to favorable exploration regions on lower Cambrian Xiaoerbulake formation, Tarim Basin. Acta Sedimentologica Sinica 33 (2): 408-415 (in Chinese with English abstract).

Zhao, Z.J., J.H. Luo, Y.B. Zhang, X.N. Wu, and W.Q. Pan. 2011. Lithofacies paleogeography of Cambrian sequences in the Tarim Basin. Acta Petrolei Sinica 32 (6): 937-948 (in Chinese with English abstract).

Zheng, J.F., Y.Q. Chen, L.L. Huang, W. Yan, X.F. Ni, B.H. Li, and X.Y. Guo. 2019. Reservoir modeling of the lower Cambrian Xiaoerblak formation in the Sugaitblak section and its significance for exploring regions in the Tarim Basin, NW China. Acta Sedimentologica Sinica 37 (3): 601-609 (in Chinese with English abstract).

Zhu, M.Y., A.H. Yang, J.L. Yuan, G.X. Li, J.M. Zhang, F.C. Zhao, S.Y. Ahn, and L. Y. Miao. 2019. Cambrian integrative stratigraphy and timescale of China. Science China Earth Sciences 62 (1): 25-60.

\section{Publisher's Note}

Springer Nature remains neutral with regard to jurisdictional claims in published maps and institutional affiliations.

\section{Submit your manuscript to a SpringerOpen ${ }^{\circ}$ journal and benefit from:}

- Convenient online submission

- Rigorous peer review

- Open access: articles freely available online

High visibility within the field

- Retaining the copyright to your article

Submit your next manuscript at $\boldsymbol{\nabla}$ springeropen.com 